\title{
BOREAS
}

\section{Middle Pleistocene ice-marginal sedimentation in the transitional zone between constrained and unconstrained ice-sheet margin, East Anglia, England.}

\begin{tabular}{|r|l|}
\hline Journal: & Boreas \\
\hline Manuscript ID & BOR-019-2016.R3 \\
\hline Manuscript Type: & Original Article \\
\hline Date Submitted by the Author: & n/a \\
\hline Complete List of Authors: & $\begin{array}{l}\text { Leszczynska, Karolina; University of Cambridge, Geography } \\
\text { Boreham, Steve; University of Cambridge, Geography } \\
\text { Gibbard, Phil; University of Cambridge, Geography; }\end{array}$ \\
\hline Keywords: & $\begin{array}{l}\text { glacial sedimentation, ice-marginal sedimentation, fan, Great Britain, North } \\
\text { Sea }\end{array}$ \\
\hline &
\end{tabular}




\section{KAROLINA LESZCZYNSKA, STEVE BOREHAM AND PHILIP L. GIBBARD}

\section{Leszczynska, K., Boreham, S. \& Gibbard, P. L.: Middle Pleistocene ice-marginal}

3 sedimentation in the transitional zone between the constrained and unconstrained ice-

4 sheet margin, East Anglia, England.

5 It is uncommon in the North Sea basin and north-western Europe for the ice-marginal glacial

6 successions of the Middle Pleistocene, Anglian (Elsterian) age to be well preserved and not 7 overridden by subsequent glaciations. The existence of extensive and thick $(\sim 20 \mathrm{~m})$ Middle

8 Pleistocene sand and gravel successions in East Anglia, England provide a unique opportunity

9 to reconstruct and understand the palaeoenvironmental conditions in the Anglian ice-marginal

10 zone, and further across the North Sea basin. This paper uses data from 80 sections in two

11 sand and gravel quarries in East Anglia to provide the first evidence concerning: i) the

12 character of the ice-marginal processes in the unique, transitional zone between the

13 topographically-constrained and unconstrained Anglian ice-sheet margin; ii) the role of

14 meltwater in the re-shaping of topographically-driven pre-glacial drainage; and iii) the

15 position and the number of oscillations of the Anglian ice-sheet margin in the form of a

16 sediment-landform assemblage. Moreover the current research adds to the discussion on the

17 presence and extent of the pro-glacial lake in the North Sea Basin during the Anglian

18 glaciation. The sand and gravel successions in the Anglian ice-marginal zone are primarily

19 reworked proto-Thames sediments deposited by meltwater. At the beginning of the glaciation,

20 the meltwater followed the pre-glacial (proto-Thames) river course. However, as the ice-sheet

21 advanced, it was re-routed, overwhelming and abandoning the old river course and depositing

22 an extensive ice-marginal subaqueous fan. The succession includes evidence for at least two

23 enhanced meltwater release events, as well as indications of glaciolacustrine sedimentation.

24 The character of the described sedimentary settings is discussed in the wider context of the 25 presence of the North Sea Lake. 
27 Karolina Leszczynska (km429@cantab.net),

28 Steve Boreham (sb139@cam.ac.uk) and

29 Philip L. Gibbard (plg1@cam.ac.uk)

30 Cambridge Quaternary, Department of Geography, University of Cambridge, Downing

31 Place, Cambridge CB2 3EN, England, UK

32 
33 East Anglia, England, is one of only a few areas in the North Sea basin and north-western

34 Europe where the deposits and landforms of the Anglian age, equivalent to the Elsterian in 35 north-western Europe (480-420 ka BP) have not been overridden by subsequent glaciation, 36 and ice-marginal sediment-landform assemblages are preserved (Fig. 1A). Here, during the 37 Anglian glaciation, the ice-sheet overrode the pre-existing River Thames Kesgrave Formation 38 deposits of the pre- and early-Anglian age, contributing to the diversion of the river (Fig. 1B, 39 C) (Bristow 1985; Gibbard \& Allen 1994; Lucy 1999). At this time, the ice-front in this area 40 abutted the significant, elongated, London Clay ridge, named the Danbury-Tiptree ridge, 41 formed south-west of the town of Colchester. This major barrier prevented the ice from 42 expanding further to the south-east (Bristow 1985). Parallel to the ridge, on its north-western 43 slopes, on the stoss side towards the ice-sheet, a deep channel has been cut within the London 44 Clay and filled with Quaternary deposits. The channel ends in the vicinity of Colchester 45 (Bristow \& Lake 1975; Bristow 1985) (Fig. 1D).

46 In contrast, to the north-east of Colchester, the ice-front was unconstrained: freely47 flowing, not constrained by any obstruction (Ellison \& Lake 1986). Here the London Clay 48 creates a low-lying landscape, and the Anglian ice-sheet margin terminates on flat ground, 49 allowing the meltwater to accumulate outwash deposits in a pattern of discontinuous 50 proglacial landforms (Bristow \& Lake 1975; Bristow 1985) (Fig. 1D).

52 been identified in the Birch-Stanway area, the current research area, to the south-west of 53 Colchester. There, extensive and thick successions of Middle Pleistocene sediments, mainly 54 sand and gravel, have been deposited (Fig. 1D, E). As this is a distinctive sedimentary setting, 55 unlike any other within the boundaries of the Middle Pleistocene ice-sheets in north-western 56 Europe, the site represents a valuable opportunity for the exploration of unusual 57 environmental contexts. 
Moreover, the Birch-Stanway area is located in the south-western periphery of the North Sea basin. During the Anglian glaciation, the British and north-European ice-masses were confluent, blocking the North Sea basin in the northern part, preventing water from escaping to the North Atlantic. They created an extensive closed, freshwater body - the North Sea Lake (Fig. 1A). The lake has been drained through the Weald-Artois (Roep et al. 1975; Gupta et al. 2007; Toucanne et al. 2009a; 2009b). The water level in the North Sea Lake depended on the interplay between the meltwater and the north European rivers inwash, the isostatic depression of the surrounding area and elevation of the basin. The sedimentological evidence for the presence of this lake is in the form of waterlain glacial diamictons and meltwater sediments constituting delta and lake-bottom deposits in northern and eastern East Anglia (Kazi \& Knill 1969; Banham 1970; Gibbard 1980; 1988; Gibbard \& Zalasiewicz 1988; Banham 1988; Lunkka 1988; Eyles et al. 1989; Lunkka 1991; Hart 1992, 1994; Lunkka 1994; Gibbard 1995; Moreau \& Huuse 2013). There is still no direct sedimentological evidence for the North Sea Lake deposits in the southern part of the North Sea at the Dutch coastline, nor in northern Germany. Instead of supposed glaciolacustrine sedimentation (Cohen et al. 2008) there exist extensive sub-glacial tunnel valleys (Stackebrandt 2009; Ehlers et al. 2011). It has been suggested that the glaciolacustrine deposits identified within the North Sea Basin represent numerous separate glacial lakes and tunnel valleys, partly filled with glaciolacustrine deposits, associated with the Anglian ice-sheet (Laban \& van der Meer 2011). As the debate on the precise extent and timing of the North Sea Lake and its water level continues, knowledge of the Birch-Stanway area would provide some of the missing evidence concerning the presence of the lake.

The new sedimentological, lithological and geophysical observations presented in this paper can be used to critically evaluate existing hypotheses by illustrating the unique palaeoenvironment in which the sediments were deposited. The aims of the current study are: 
83 i) to investigate the sedimentary succession; ii) to reconstruct the palaeoenvironment of 84 deposition; iii) to explore the depositional domain at the transition between the 85 topographically constrained and unconstrained ice-front; iv) to discuss the role of the preexisting River Thames and Anglian ice-marginal meltwater drainage in the shaping of the sedimentary succession and palaeogeography of this area; v) to reconstruct the position of the Anglian ice-sheet margin and the number of enhanced meltwater release events; and finally vi) to open the discussion concerning the possible connection between the Anglian ice-sheet margin and the North Sea glacial lake.

\section{Study area}

In the Birch-Stanway area, the ground surface is gently inclined from $61 \mathrm{~m}$ Ordnance Datum (OD) in the north-west, in vicinity of Birch Quarry (National Grid Reference: TL 592000 218000), to $19 \mathrm{~m} \mathrm{OD}$ in the south-east near Abberton Reservoir (TL 595000 216000; Fig. 1E). The bedrock here is composed of the Tertiary (Paleogene) London Clay of the Thames Group, the surface of which dips gently to the south (Bell 1985). In the north-western part of the research area, the London Clay is overlain by $\sim 15-26 \mathrm{~m}$ of unconsolidated Middle Pleistocene deposits. The Pleistocene sediments become discontinuous south-east of the B1022-Birch Quarry-Stanway Quarry line. There the London Clay forms outcrops at the surface in an area of low relief (Ambrose 1975) (Fig. 1E).

Despite the numerous accounts of the geology of the Birch-Stanway area (Ambrose 1973, 1974, 1975), the British Geological Survey (BGS) Memoir (Ellison \& Lake 1986), extensive borehole data (available at the BGS) and unpublished site reports (Bell 1985; Arditto 1995; Bailey 1995), there remains no consensus regarding the palaeoenvironment of deposition of the Middle Pleistocene sediments and several hypotheses have been proposed. The deposits in the Birch-Stanway area have been interpreted to be of varying origins: i) glacial sediments of the Lowestoft Formation (Anglian age) deposited in a pro-glacial lake 
108 (Bell 1985; Bailey 1996); ii) fluvial sediments of the Kesgrave Formation (pre- and early-

109 Anglian age) deposited by the pre-diversion River Thames (Arditto 1995) or iii) sediments of 110 mixed glacial and fluvial origin (Bristow \& Lake 1975; Bristow 1985; Ellison \& Lake 1986).

111 Similarly, no definite conclusions were drawn by the research on the lithological

112 composition and the provenance of the deposits in the Birch-Stanway area. The glacial

113 Lowestoft Formation sand and gravel (Anglian age) and the fluvial Kesgrave Formation

114 deposits (pre- and early-Anglian age) are not completely lithologically distinct and all

115 differences tend to be local and site-specific (Table 1, 2) (Hey 1965, 1976; Hey \& Brenchley

116 1977; Green \& McGregor 1978; Green et al. 1980; 1980; 1982; Bridgland 1983a,b;

117 McGregor \& Green 1986). In the vicinity of the Birch-Stanway area, deposits correlated with

118 the Lowestoft Formation have been described at all elevations above sea level, while those

119 defined as Kesgrave Formation have only been found between 15 and 20 m OD (Bristow

120 1985; Ellison \& Lake 1986).

121 Methods

122 The investigations of the sedimentary succession in the Birch-Stanway area were undertaken 123 at two quarries (Fig. 1D, E): Stanway (Fig. 2) and Birch (Fig. 6), where the Quaternary 124 deposits are 21 and $26 \mathrm{~m}$ thick, respectively. The exposures were divided into faces 125 (continuous exposures) and sections (localised exposures within faces). In total, 80 sections 126 (54 in 13 faces at Stanway, 26 in 13 faces at Birch) were photographed, sketched to scale and 127 presented as vertical profile logs (Krumbein 1937; Krumbein \& Pettijohn 1938; Jones et al. 128 1999; Evans \& Benn 2004). All the localities were mapped and surveyed relative to Ordnance 129 Datum (OD) using a Leica SmartNet Global Positioning System (GPS) system. Information 130 was gathered on the primary sedimentary structures, texture, sorting of sediments, spatial 131 relations and contacts between discrete beds. The main palaeoflow direction was determined 132 on the basis of the dip diections of the planar cross-beds (ripples) and foresets of dunes. The 
133 identification of the foresets and backsets allowed the main palaeoflow direction to be

134 determined. For the purpose of the publication, data were presented in form of photopanel,

135 line-drawings (Figs. 2, 6) and composite logs (Figs. 3, 7) of the exposures critical for

136 understanding the whole succession. Additional section logs and their correlation are

137 presented as Supporting Information (Fig. S1-5).

138 The collected observations were used to divide the sediment into discrete sedimentary

139 facies (Eyles et al. 1983; Evans \& Benn 2004). The facies were coded based on Miall (1977;

140 1985) and Maizels (1993, 1997) (Table 3) and grouped into facies associations, herein further

141 referred to as FA, as they occur together most often in the field (Table 4). The analysis of

142 these associations allowed the palaeoenvironments of the deposition to be reconstructed.

143 The section logging at Stanway Quarry was supplemented by a ground penetrating

144 radar (GPR) survey. The GPR was deployed in common off-set mode, with two separate

145 transmitting and receiving shielded $100 \mathrm{MHz}$ antennae. The transects were conducted

146 according to Regli et al. (2002) and Beres et al. (1995). The raw data were post-processed

147 using RADAN software. After the surface position adjustment (time zero drift) and surface

148 normalization, the sequence of processing steps consisted of: i) background removal; ii)

149 vertical and horizontal high and low pass filter; iii) migration; iv) deconvolution and v) gain

150 adjustment. The GPR data was interpreted using radar stratigraphy (Gawthorpe et al. 1993;

151 Neal 2004), based on the recognition of radar surfaces (RS) and radar facies (RF). The radar

152 facies were used to identify the facies and their extent in unexposed or partially-exposed

153 areas. To correlate the GPR transects with the sedimentary facies and boundaries exposed, a

154 control transect (transect 1, Fig. 4A, B) was placed above the exposure, so that the radar

155 facies and radar surfaces could be correlated with real sedimentary facies and boundaries of in

156 situ deposits. Morover, two control boreholes were laid in line with the GPR transects (bhS1

157 and bhS2; Fig. 5A). 
158

159

160

161

162

163

164

165

166

167

168

169

170

171

172

173

174

175

176

177

178

179

180

181

182

Borehole data from the BGS archives was used to contextualise the field observations. The original descriptions of the deposits within the boreholes were unified prior to interpretation and divided into one of three main categories: i) gravelly, ii) sandy or iii) diamicton facies. Rockworks software was employed to construct geological cross-sections based on the collected borehole data (Fig. 5).

Clast lithological analysis (CLA) was used to trace the origin of the sand and gravel deposits. Samples taken from exposures were analysed at the Physical Geography Science Laboratories at the University of Cambridge, according to Bridgland (1986), with four size ranges adopted: $8-11.2,11.2-16,16-32$ and $>32 \mathrm{~mm}$. These size ranges were chosen so that pebbles were clearly identifiable, but also to allow for comparison with previous research. A minimum number of 700 clasts was counted in each sample, and the typical sample size was $\sim 15-20 \mathrm{~kg}$. Based on the literature, a clast reference collection was prepared. The presence of angular, nodular and rounded flint, as well as Rhaxella Chert (Table 2), was interpreted as evidence for the glacial origin of deposits of the Lowestoft Formation (Hey 1976; Green et al. 1980). In contrast, lithologies such as quartz, quartzite, sandstone, siltstone, pinhole chert (Hey 1965, 1976), Greensand chert (Green \& McGregor 1978; Bridgland 1986), volcanic and igneous rocks (Table 2), were defined as characteristic of deposits brought into the area by the proto-Thames river and its tributaries, prior to the Anglian glaciation (Hey 1965, 1976; Green \& McGregor 1978; Bridgland 1986, 1988). The characteristics of all lithological types is given in Table 2 and clast lithological analysis results of this and previous research is given in Tables 1 and 5 .

\section{Sedimentary facies and depositional geometries}

The deposits described from the Birch-Stanway area were characterised in terms of their lateral and vertical facies association relationships. The gravelly facies association G1 and G3 and clay, silt and sand of F1 are present only at Stanway Quarry, while the deformed sand of 
183 S1 and diamicton of D1 are only characteristic of the Birch Quarry exposures. The remaining

184 gravelly G2 and sandy S1 facies associations occur at both sites. The Middle Pleistocene sand 185 and gravel deposits at the Birch and Stanway quarries rest on a highly undulating erosional 186 surface of Tertiary London Clay at $\sim 15-18 \mathrm{~m}$ OD. The deposits, particularly the pebble to 187 cobble fraction running throughout all the exposures/units within both sites, have a similar 188 lithology: angular flint prevails with an admixture of rounded flint, quartz and quartzite. Other 189 lithologies occur in negligible amounts (Table 5).

\section{Stanway Quarry deposits}

191 All the facies associations described from Stanway Quarry create thick, tabular persistent 192 units and all, with the exception of facies association F1, laterally extend throughout the area 193 of the quarry. The overall geometry of all the beds is subhorizontal. The area covers $\sim 600 \mathrm{~m}$ 194 from north to south, in the flow direction, from the ice-proximal to the ice-distal area, and $195 \sim 500 \mathrm{~m}$ from west to east, across the direction of flow, roughly along the predicted ice-sheet 196 margin (Fig. 2A inset). The ground surface within this area dips gently towards the south, 197 from $\sim 40 \mathrm{~m}$ OD in the northernmost to $38 \mathrm{~m} \mathrm{OD}$ in the southernmost part of the Stanway 198 Quarry. The succession overlying the London Clay at Stanway Quarry varies along the 199 palaeoflow direction from the north-north-west to the south-south-east: i) there is a fining 200 particle size trend within the discrete sedimentary units and ii) gravel-rich deposits pass into 201 sandy deposits. The deposits from Stanway Quarry were described in stratigraphical order, 202 from bottom to the top, starting with the basal gravelly facies association G1 deposited within 203 the erosional, elongated depression located in the central area of the quarry working. In order 204 to depict the vertical and lateral (in flow direction) changes of facies association, the 205 description of the deposits overlying unit G1 was grouped into the description of the 206 sediments from the northernmost part of the quarry, the middle part of the quarry (located 350 
207 m towards the south, in flow direction) and the southernmost part of the quarry (located 200 $208 \mathrm{~m}$ towards the south, in flow direction).

209 The lower boundary of the lowermost, distinctive G1 gravelly facies association is not 210 exposed and the upper boundary is only partially exposed (Fig. 2G). The GPR was deployed 211 to describe the dimensions of unexposed unit G1 under the quarry floor. The results show that 212 this facies association, represented by radar facies RF1, reaches 4-6 m below the base of the 213 quarry, to $\sim 13-15$ m OD. G1 rests directly on the London Clay (transect 1 and 2, boreholes 214 bhS1, bhS2; Fig. 4) filling an elongated erosional, channel-like depression aligned from the 215 south-west to the north-east within the quarry. Transect 1 cuts across the feature and shows 216 the boundary of the depression (50-60 m along transect 1; Fig. 4B). The channel is $\sim 3-3.5 \mathrm{~m}$ 217 deep and excess $60 \mathrm{~m}$ in width. The GPR trace of the gravelly unit G1 (RF1; Fig. 4C, D) does 218 not show distinctive signature beside few lobe-shaped features within the transect 2 (Fig. 4C). 219 On the contrary within the GPR trace of unit G2 (RF2 and 3) there are low-angle clinoforms 220 (RF2; Fig. 4B) and lobe shape features defined as convex-up architectural elements (RF3; Fig. 221 4C) identified.

222 Facies association G1 comprises pebble to cobble, poorly-sorted gravel and represents 223 the only unit where the gravel fraction $>16 \mathrm{~mm}$ exceeds $25 \%$ of the total volume of the 224 sample. This is the coarsest facies association in the whole succession. Moreover, this is the 225 only unit where clay intraclasts (nodules, rip-up clasts derived from the underlying London 226 Clat) occur.

227 Crudely horizontally-stratified gravel of G1 (Table 4) is arranged in places in faint 228 trough cross- and solitary planar cross-stratifications (angle of $10-15^{\circ}$ ). Within generally 229 matrix-supported sediments, units of clast-supported to open-work gravel occur, especially 230 within solitary planar cross-beds (dip up to $\sim 20^{\circ}$ ). Tabular and lenticular beds of massive to 231 diffusely horizontally-bedded pebbly sand are present. Frequent erosional surfaces and scour 
232 fills cut the deposit. The scour fills are 0.1-0.4 $\mathrm{m}$ deep and laterally extend for $\sim 20 \mathrm{~m}$. They 233 are filled with massive to cross-stratified matrix supported to openwork gravel (cross-strata 234 dip at an angle of $\sim 15-20^{\circ}$ ). The solitary cross-strata dip towards the east and north-east and 235 imbricated clasts with a-axis transverse and b-axis inclined - a ( $\mathrm{t}$ ) and b (i); dip towards the 236 west. Across-flow a-transverse orientated pebbles confirm the direction of the axis of the 237 palaeocurrent.

238 Filling an elongated erosional, channel-like depression, facies association G1 is not 239 present within the whole quarry working. In the northernmost part of the quarry (for location 240 see Fig. 2A inset), at the point most proximal to the ice-sheet margin (Fig. 2A-E), the entire 241 thickness of the succession overlying the London Clay, consists of two juxtaposed units of 242 gravel of facies association G2. The entire exposed thickness of the lower unit of facies 243 association G2 here (from 21 to 33 m OD) comprises massive to horizontally diffusely244 stratified gravel (Fig. 2B-D). Within the upper level of G2, massive to horizontally diffusely245 stratified gravel is interbedded with massive to planar parallel-bedded sand which is only 246 occasionally planar cross-bedded (angle of dip $<20^{\circ}$; Fig. 2E-H). These continuous, tabular 247 gravel and sand units laterally extend for a few hundreds of metres. Here, the beds of gravel 248 are up to few metres thick, while the beds of sand are a few decimetres thick. Within both 249 levels imbricated clasts are observed; they dip towards the north with a-axis transverse and b250 axis inclined - a ( $\mathrm{t}$ ) and $\mathrm{b}(\mathrm{i})$. This unit of G2 is truncated at the level of 32-33 $\mathrm{m}$ OD by a 251 sharp horizontal, easily distinguishable boundary associated with an erosional surface or a 252 break in sedimentation (hereafter referred to as ES). From this level it is penetrated by two to 253 two and a half metre-deep ice-wedge casts (Fig. 2E). These ice-wedge casts occur every 1025415 metres along the face and are present only in the northernmost part of the quarry where the 255 succession cosists only of the overlying units of gravel of G2. 
When comparing both juxtaposed units of gravel G2, the maximum clast size in the 257 upper unit (mean D-value between 8.8 and $9.67 \mathrm{~mm}$, with $5-11 \%$ of a sample $>$ than $16 \mathrm{~mm}$ ) 258 is smaller than in the lower one (mean D-value between 12.07 and $13.26 \mathrm{~mm}$, with $30-46 \%$ of 259 a sample $>$ than $16 \mathrm{~mm}$ ). The uppermost sediments within the upper unit of G2, which 260 reaches up to $39.5 \mathrm{~m} \mathrm{OD}$, are red-stained. From this locality towards the south south-east of 261 the quarry working, in the flow direction, the gravel of both, lower and upper unit of G2, 262 becomes finer, the proportion of sand within matrix increases and sandy beds become thicker 263 at the expense of the gravel beds (Fig. 2F and the general stratigraphy of this part of the 264 quarry in form of the composite $\log \mathrm{SC} 1$ in Fig. 3).

265 In the middle part of the Stanway Quarry, about $350 \mathrm{~m}$ further south of the 266 northernmost exposures, along the palaeoflow direction, the succession consists of basal 267 gravelly facies association G1 described from the elongated depression within the London 268 Clay, overlain by gravel of facies association G2 (from 17.5-18 to 20-21 m OD) in places 269 laterally gradually changing into facies association G3, both overlain by sandy facies 270 association $\mathrm{S} 1$ (from 20-21 to $30 \mathrm{~m} \mathrm{OD),} \mathrm{capped} \mathrm{with} \mathrm{sand,} \mathrm{silt} \mathrm{and} \mathrm{clay} \mathrm{facies} \mathrm{association} \mathrm{F1}$ 271 (from 30 to $31 \mathrm{~m} \mathrm{OD)}$ ) and again, the upper unit of gravelly facies association G2 (from 31 to $27239 \mathrm{~m}$, the ground surface) (photopanels in Fig. 2G-J and composite log SC2 in Fig. 3). The 273 boundaries between all the units are gradational, with the exception of the base of the upper 274 unit of gravel G2, which is erosional.

275 In exposure (Fig. 2G) and in the GPR the boundary between gravelly unit G1 (RF1) 276 and G2 (RF2 and RF3) is undulating, sharp, but non-erosional. While the gravelly unit G2, 277 overlying G1, displays the same characteristics described from the northernmost part of the 278 quarry, in this area, it is thinner and reaches $\sim 20-21 \mathrm{~m} \mathrm{OD}$. In this part of the quarry in places 279 G2 is replaced by distinctive large-scale planar cross-stratified gravel of facies association G3 280 (Figs. 2M, 3). It extends laterally for $>150 \mathrm{~m}$ (accurate lateral extent is obscured by slump 
281 deposits of a quarry face). Due to the inaccessibility of exposure, it was not possible to trace 282 whether the lateral change between G2 and G3 is gradational or sharp and erosional. The unit 283 of planar cross-bedded gravel is $\sim 1.5 \mathrm{~m}$ thick. It is underlain and overlain with gravel of the 284 lower unit of facies association G2. The lower boundary of G3 is erosional, while the upper is 285 sharp, but non-erosional. The individual beds dip with an angle between $15-22^{\circ}$ towards the 286 east, and south east and west within a single outcrop.

287 Both gravelly facies associations G2 and G3 are overlain by sandy deposits of S1 at 288 the level of $21 \mathrm{~m} \mathrm{OD}$ (Fig. 2M-R). The high variability of sedimentary structures and the 289 rapid transition between structures and individual beds is typical of this association. It 290 comprises lenticular and tabular discontinuous beds of planar parallel-, planar cross- and 291 trough cross-bedded sand with small lenses of cross-stratified granule gravel. The individual 292 beds of planar parallel- and planar cross-bedded sand are 10 to $40 \mathrm{~cm}$ thick, which are only 293 occasionally thicker and extend laterally for a few metres. The lenses of granule gravel are up 294 to $40-50 \mathrm{~cm}$ thick and laterally do not exceed $2 \mathrm{~m}$. The planar cross-beds within the sandy 295 deposits dip towards the south-east with an angle of $10-12^{\circ}$. Multiple erosional scours and 296 chutes-and-pools are also described from this unit (Fig. 2M-R). The chutes and pools are 297 filled with planar to sigmoidal and concave-up, downflow-divergent cross-beds and rare 298 boundary conformable laminae. Cross-beds within these features, which constitute backsets 299 (based on comparison with the palaeoflow direction indicated by planar cross-beds) dip 300 towards the north and north-west with an angle of $<10^{\circ}$. The erosional scours are filled with 301 sigmoidal cross-beds. Individual beds of planar parallel- and planar cross-bedded sand are 10 302 to $40 \mathrm{~cm}$ thick, thickening occasionally and extending laterally for a few metres. Likewise, 303 erosional scours and chute-and-pools are 10 to $50 \mathrm{~cm}$ deep and span a few metres in lateral 304 extent. 
305 At a level of $\sim 29.6 \mathrm{~m} \mathrm{OD}$, unit F1, consisting of recurring cycles of fining-upwards 306 sand, silt and clay (Fig. 2J-L), is identified above sandy facies association S1. Within these 307 successions, massive or small scale planar and climbing ripple cross-laminated sand fines 308 upwards into planar parallel-laminated to massive silt and clay. The beds of sand are between 30910 and $20 \mathrm{~cm}$ thick, whilst the beds of silt and clay are a few $\mathrm{cm}$ thick. Unit $\mathrm{F} 1$ is absent 310 towards the north of this locality, but gradually thickens towards the south. In places where 311 recurring cycles of sand, silt and clay are few tens of centimetres thick, they are overlain with 312 very stiff, massive clay and silt. This unit is overlain by an upper unit of gravel of G2 at the 313 level of $31 \mathrm{~m} \mathrm{OD.}$

314 In the southernmost part of the quarry, another $200 \mathrm{~m}$ further towards the south in the 315 flow direction, the exposures show a succession of the gravel of G2, overlain by the sand of 316 S1, the sand silt and clay of F1 and again the gravel of G2 continues with only two 317 alternations: i) the size range and the percentage of gravel particles within the upper unit of 318 G2 decreases, and ii) the sand, silt and clay unit F1 thickens to reach $>1 \mathrm{~m}$ (between 28.9 and $31930 \mathrm{~m} \mathrm{OD}$ ) in the southernmost exposures of the quarry (Fig. 2K).

320 Along the western exposures within the quarry, the succession is similar to that 321 presented above from the eastern part, but lack the units of the lowermost gravel of G1 and 322 cross-stratified gravel of G3. In the western part of the quarry, as in the eastern part, the lower 323 unit of gravel of G2 gradually changes into the sandy unit of S1. Further south, unit F1 324 appears between the sandy deposits of S1 and the upper unit of gravel of facies association 325 G2. All the sedimentary characteristics of these units are as described from the eastern part of 326 Stanway Quarry.

327 All the sedimentary units described above dip gently towards the south, i.e. in the 328 direction of the palaeoflow. This is demonstrated by the dip of the base of the upper unit of 
329 gravel G2: from $32 \mathrm{~m} \mathrm{OD}$ in the northernmost to $30 \mathrm{~m} \mathrm{OD}$ in the southernmost part of the 330 Stanway Quarry working.

331 Geological transects based on the borehole records are used to extend the entire 332 sedimentary succession described from Stanway Quarry into unexposed areas (Fig. 5A, C). 333 Three characteristics appear from the description of these transects: i) while the boreholes in 334 the north of the transect with the north-south alignment are gravel dominated, the south of the 335 succession is dominated by sandy deposits; ii) there is an apparent gravel unit which 336 consistently starts at a height of $\sim 30-31 \mathrm{~m} \mathrm{OD}$ in the north-to-south aligned transect 2 , 337 boreholes 10-20 (Fig. 5A, C); iii) the presence of the two units of gravelly deposits and sandy 338 facies between them. This pattern broadly corresponds to the succession of deposits described 339 from the quarry.

340 Birch Quarry deposits

341 The facies associations described from Birch Quarry occur as thick continuous tabular units 342 extending throughout the area of the quarry workings, $\sim 300 \mathrm{~m}$ from the north to south, in the 343 current direction, from the ice-proximal to ice-distal area and $\sim 300 \mathrm{~m}$ from the west to the 344 east, across the flow direction, roughly aligned along the predicted ice-sheet margin (Fig. 6A 345 inset). The overall geometry of all the beds described within the succession is subhorizontal. 346 The depositional succession at Birch Quarry starts with 3-4 m-thick unit of gravelly 347 facies association G2 (from 18 to 21-22 m OD) (Figs. 6B, 7) at the base of the whole quarry 348 (face I and II), where exposures can be seen. The massive to horizontally diffusely-stratified 349 gravelly beds within this unit are a few tens to a few hundreds cm thick. They are interbedded 350 with units of massive to diffusely planar, parallel- and planar cross-bedded sand and pebbly 351 sand. Individual beds of sand are ten to a few tens $\mathrm{cm}$ thick and laterally extend for more than 352 few metres. The percentage and the size of gravel particles within gravelly beds of G2 353 decreases, while the sandy units thicken to reach $>1 \mathrm{~m}$ towards the east, across the palaeoflow 
354 (Fig. 6C) and towards the south, parallel to the palaeoflow direction. The planar cross-beds 355 within the sand dip towards the south and south-east with an angle of $\sim 15^{\circ}$.

356 Towards the top of the succession, around 21-22 m OD, gravel and sand units of G2 357 gradually change into sandy deposits of S1 (Fig. 6C, D; 7). This unit can be traced 358 continuously across the quarry. The sandy deposits of this unit consist of lenticular and 359 tabular discontinuous beds of trough- and planar cross-bedded and planar-parallel pebbly 360 sand. The sand beds display subhorizontal geometry. They are cut with multiple erosional 361 surfaces and chutes-and-pools features, which are 50 to $60 \mathrm{~cm}$ deep and two to three metres 362 wide. Planar cross-beds dip towards the south and south-east with an angle of $\sim 15^{\circ}$. On the 363 contrary, within the chutes-and-pools, sigmoidal to concave-up in places downflow divergent 364 laminae show backset cross-stratification and dip steeply $\left(15-20^{\circ}\right)$ towards the north. 365 Erosional scours are filled with cross-beds characterized by the dip up to $15-20^{\circ}$.

366 At the level of $\sim 26-27 \mathrm{~m} \mathrm{OD}$, this 4-5 m-thick sandy unit (S1) is directly overlain by 367 the gravel of G2 (Fig. 6E; 7). Similarly, as in the lower unit, gravelly beds are present, 368 consisting of massive to horizontally diffusely stratified gravel a few tens to few hundreds $\mathrm{cm}$ 369 thick. They are interbedded with units of massive to diffusely planar parallel-bedded sand up 370 to $20 \mathrm{~cm}$ thick. These sandy units are discontinuous and less ubiquitous than in the lower level 371 of G2. The upper gravelly unit G2 reaches up to 30-31 m OD and the boundary at this level is 372 traceable throughout the quarry. As at Stanway, the gravel is disrupted by extensive (2-2.5 m373 deep) ice-wedge casts at this level (Fig. 6F). Ice wedge casts occur only in the north-western 374 part of the quarry (Fig. 6E, F, inset).

375 In the north-western part of the quarry, in the area proximal to the ice sheet, above 30$37631 \mathrm{~m} \mathrm{OD}$, the succession starts with the massive pebble to cobble gravel of facies association 377 G2 (Fig. 6G), the characteristics of which match those described from the lower level of 378 gravel G2. This gravel, present above 30-31 m OD in the north-western part of the quarry 
379 gradually passes towards the south and south-east (along palaeoflow direction) into sandy unit

380 S1. In the southernmost part of the quarry, distal to the ice-sheet margin, above 30-31 m OD, 381 the sandy deposits of S1 are present instead of the gravel of G2 (Figs. 6K, L, 7).

382 The gravel in the north-western part of the quarry is overlain at the level of $40-41 \mathrm{~m}$ 383 OD by a distinctive unit of deformed sand of S1 2-3 m-thick (Fig. 6I, J). The lower boundary 384 of $\mathrm{S} 1$ is sharp and undulating. The deformation structures consist of overturned and 385 recumbent folds, as well as small-scale convolute lamination. The axial plane of the fold 386 described from section I and J (Fig. 6I, J) was horizontal and followed the direction north387 north-west to south-south-east. Some of the folds were bounded by an erosional surface. The 388 deformed sandy unit thins, disappearing towards the south, in the direction of flow.

The top of the succession at Birch Quarry comprises a massive diamicton of facies association D1described from both the north-western and southern part of the quarry (Fig. $6 \mathrm{H}$, $\mathrm{K}, \mathrm{L})$. According to contextual observations this unit is continuous between these faces. In the north-west, D1 truncates the underlying deformed sand of $\mathrm{S} 1$ at a level of $\sim 43 \mathrm{~m}$ OD (Fig. $6 \mathrm{H})$. In the south-eastern part of the quarry, it directly overlies the sandy deposits of S1 (Fig. 6K, L). Beyond face XIII, diamicton D1 thins and finally disappears. The succession described above is presented in form of two composite logs depicting key localities within the quarry (Fig. 7).

398 evidence confirm the general characteristics of the succession described from the quarry 399 exposures. The presence of sand interbedded with two units of gravel and the uppermost unit 400 of diamicton D1 is confirmed in transect 1, aligned from the north-west to the south-east (Fig. $4015 \mathrm{~B}, \mathrm{D})$; however, the upper unit of deformed sand underlying D1 is not described from the 402 boreholes. The units of gravel thin from the north-west to the south-east in the downflow 403 direction, from the proximal to distal environment. In transect 2, which runs across the 
404 palaeoflow direction, towards the south, off the quarry area, all the boreholes confirm the

405 presence of gravel-dominated succession and there are no significant changes in the amount

406 of coarse-grained component along this line, with the exception of the borehole in the middle

407 of the transect (Fig. 9B).

408 Birch and Stanway Quarry deposits - interpretation

409 Glaciofluvial Facies Association (FA G1). The GPR data confirms that the gravel of G1 410 present at the base of the succession at Stanway Quarry was deposited in a south-west to 411 north-east-aligned channel eroded in the London Clay surface. The channel is $\sim 3-3.5 \mathrm{~m}$ deep 412 and excess $60 \mathrm{~m}$ in width. The secondary radar surface SRS1 described within RF1 is 413 interpreted as representing either the London Clay or a local reflector associated with the 414 presence of high concentrations of clay and silt within gravel matrix (Fig. 4).

415 The poorly sorted pebble to cobble, matrix-supported to openwork gravel of this facies 416 association indicates rapid aggradation in supercritical flow conditions. Crudely horizontally 417 stratified units are interpreted as being deposited by traction currents. The presence of 418 imbricated clasts indicates deposition taking place as a bedload 'lag' or within longitudinal 419 bars (Miall 1978). Tabular units of planar cross-stratifications represent the downflow 420 transport of bedload on a braidplain as longitudinal bars (Boothroyd \& Ashley 1975; Plink421 Bjorklund \& Ronnert 1999). Lenticular beds of massive or diffusely horizontally-bedded 422 pebbly sand are interpreted as scour-fills associated with rapid cut-and-fill processes related to 423 supercritical flow conditions (Winsemann et al. 2009; Lang \& Winsemann 2013) (Fig. 2G).

424 However in the GPR transects there are no unequivocal indications of the palaeoflow 425 direction within unit G1 (RF1), the palaeoflow direction indicated by solitary cross426 stratification and imbricated clasts within exposures of G1 points towards the east and north427 east, with the axis of the flow confirmed by the presence of a-axis transverse pebbles. 
428 The deposits of facies association G1 may be compared with either ice-proximal 429 deposition within the high energy braided environment with migrating channel bars or as jet 430 efflux sediments associated with supercritical conditions in ice-proximal environment 431 (Winsemann et al. 2009; Lang \& Winsemann 2013).

432 Subaqueous Fan Facies Association (FA G2, G3, S1). The basal portions of the gravelly 433 facies G2 are well depicted within the GPR transects (Fig. 4). The undulating lower boundary 434 of this unit is here confirmed. The low angle clinoforms within unit G2 (RF2) are 435 aggradational forms, which confirm the direction of palaeoflow as described from exposures 436 (Fig. 4B). The lobe shape features shown by the GPR traces within unit G2 (RF3) across flow 437 are compared with features typical for fan or shallow-water delta deposits (Fig. 4C).

438 Facies association G2 in the northern part of both sites displays the characteristics of 439 sediments rapidly deposited from sediment-laden flow in a high-energy environment, with 440 high competence and discharge (Collinson \& Thompson 1989) (Fig. 4B-D). The lack of 441 erosional zones and lack of channel-like features confirm the presence of sediment 442 overloading (Postma 1986). Such substantially thick, persistent units of matrix-supported, 443 massive gravel, as represented by the lower unit of G2, are known to result from supercritical 444 sheetflows (Krzyszkowski \& Zielinski 2002), non-cohesive debris flow (Shanmugam 2000) 445 or rapid sedimentation from sediment density flow (Postma 1986). Horizontally diffusely446 stratified gravel was deposited from traction in lower concentration portions of the flow 447 (Plink-Bjorklund \& Ronnert 1999) or gravelly antidunes (Lang \& Winsemann 2013). The 448 poor sorting and coarse character of the deposits indicate a short transport path. The presence 449 of imbricated clasts indicates palaeoflow towards the south.

450 Beds of massive sand within facies association G2 were deposited from the sandy 451 debris flow, from suspension, following the deceleration of high-velocity sediment-laden flow 452 (Maizels 1993; Shanmugam 2000; Bennett et al. 2002; Tucker 2006; Winsemann et al. 2009). 
453 The laminated sand was deposited by traction from lower concentration turbidity flows or

454 flush floods under the conditions of an upper flow regime with a plane bed (Miall 1977).

455 Small-scale cross-beds present in places within the sand indicate deposition within migrating

456 sandy bars or dunes. Stacked successions of gravelly facies and massive, laminated and cross-

457 bedded sand may also be interpreted as antidunes or humpback dunes. The downcurrent dip of

458 the planar-cross beds indicates the palaeocurrent direction towards the south-east, as predicted

459 for the meltwater from the Anglian ice sheet in this part of England, and roughly

460 perpendicular in relation to gravel of G1.

461 Within both levels of facies association G2 at both sites, an apparent downcurrent and

462 upward-fining trend can be seen. The decreasing size of clasts and percentage amount of

463 gravel within the deposit towards the south-east (Fig. 2F) is evidence for two possible

464 scenarios: i) a downcurrent flow transition, i.e. a rapid decrease of flow competency and

465 energy of transport associated with flow splitting during fan/delta aggradation, or ii) a

466 progressive decline in a sediment load, i.e. rapid deposition of the coarse-grained component

467 at the beginning of the transport path, after/during a hydraulic pulse (Marren 2001; Bennett et

468 al. 2002). The smaller maximum clast size in the upper unit of G2 is evidence of relatively

469 lower energy of transport and deposition than in the lower unit of G2, or a longer distance

470 with respect to the source area, in this case the ice front. The presence of well-developed ice-

471 wedge casts (Fig. 2E)at the level of 30-31 m OD within the uppermost part of the unit G2,

472 indicates sub-aerial exposure of the deposits in a dry and cold climate.

473 The well-developed cross-stratification within the gravel of G3 in the southern part of

474 Stanway Quarry (Fig. 2M), dipping towards the south-east and west, may be interpreted as i)

475 the shallow-water mouthbar delta (Ashley \& Smith 1985; Glanville 1997) or ii) the remnants

476 of migrating two- or three-dimensional dunes. In the first, most probable scenario, the variety

477 of palaeocurrent directions, which fit to the geometry of a delta lobe, results from the fact that 
478 the delta can prograde into a water body both longitudinally and laterally in relation to the 479 delta apex. In pro-glacial conditions, its orientation is independent of the ice-front orientation 480 (Clemmensen \& Houmark-Nielsen 1981). The lateral extent of the foresets (a few hundreds of 481 metres) precludes a large scour-fill origin for these foresets. In the second case, the migration 482 of dunes requires constant discharge conditions for a long time period (Reineck \& Singh 483 1980; Mulder \& Alexander 2001; Benn \& Evans 2002). As the wavelength of dunes 484 influencing the size of developed cross-stratification is scaled to water depth, the significant 485 thickness of the G3 bed in the $1.5 \mathrm{~m}$ range may indicate a significant depth of flow (Fielding 486 2006).

487 Facies association S1 is characterized by the high variability and rapid transitions 488 between various sedimentary structures (Fig. 2N-R). These are caused by changes in the 489 physical properties of the flow. Here, the fluctuating hydraulic conditions are related to either 490 intrinsic variations of depth and velocity typical of transcritical and supercritical flow, or 491 varying supplies of sediment and flow density (Miall 1977; Reineck \& Singh 1980; Miall 492 1985; Alexander et al. 2001; Benn \& Evans 2002). The presence of planar cross- and trough 493 cross-bedded sand and pebbly sand with lenses of cross-stratified granule gravel is interpreted 494 as the remnants of migrating two- and three-dimensional dunes (Church \& Gilbert 1975; 495 Smith 1985; Alexander et al. 2001; Marren 2001; Russell \& Arnott 2003). These unconfined 496 large-scale migrating bedforms are typical of a subaqueous setting with sustained high energy 497 currents. Chute-and-pools filled by planar to sigmoidal cross-beds dipping upstream, towards 498 the north and north-west (the paleocurrent direction confirmed by tabular units of planar 499 cross-beds) are scoured upflow submerged hydraulic jumps, under conditions of dilution, 500 reduced velocity and competence of flow. The backset cross-stratification may also be 501 evidence for downflow-migrating humpback dunes (Massari 1996; Duller et al. 2008; 502 Cartigny et al. 2012) typical of transcritical flow conditions (Lang \& Winsemann 2013). 
503 Fine-grained glaciolacustrine Facies Association (FA F1). The distinctive fine character of

504 facies association F1 (Fig. 2I-L) indicates deposition in a lower flow regime setting. Planar 505 parallel-laminations are associated with deposition from traction in conditions of 506 decelerating/expanding flow, while climbing cross-stratification indicates high rates of 507 sedimentation under conditions of waning flow (Ashley et al. 1982). The uppermost part of 508 this facies association, comprising stiff, massive to faintly planar-parallel laminated silt and 509 clay, represents deposits of waning, low density turbidity currents or sedimentation from 510 suspension within an extensive water body, i.e. a glaciolacustrine environment. Similarly, the 511 apparent cyclic pattern of depositon presented by sandy silt and clay facies association F1 in 512 pro-glacial conditions is typical of a lake setting with minimal meltwater discharge (Jopling \& 513 Walker 1968; Rust \& Romanelli 1975; Reineck \& Singh 1980; Collinson \& Thompson 1989; 514 Russell \& Arnott 2003).

515 Glacial diamicton FA D1. The two uppermost facies associations described from the north516 western part of the Birch Quarry, deformed sand facies S1 (Fig. 6H-J) and diamicton D1 (Fig. $5176 \mathrm{H}, \mathrm{K}, \mathrm{L}$ ), are interpreted as direct evidence of liquefaction of desposits and the presence of 518 an ice-mass in form of glacial ice-lobe in this locality. Facies D1, present only at Birch 519 Quarry, is interpreted as a diamicton deposited by i) solifluction or ii) directly from the ice 520 sheet. The diamicton of unit D1 marks the maximum extent of the ice sheet in this area.

\section{Synthesis and discussion}

522 The succession described from the two quarries at Birch-Stanway area are illustrated in the 523 schematic cross sections in Fig. 8 (Supporting Information Fig. S6 - with location of 524 sections). There are several common features of both sites: i) the facies associations create 525 thick, tabular, laterally continuous units, which indicate high aggradation rates and stable flow 526 and discharge conditions within the time-space of a single water-release; ii) discrete bed dips 527 are only in a range of few degree - the overall large scale geometry is subhorizontal; iii) an 
528 erosional boundary/break in sedimentation surface associated with periglacial features divides 529 the succession at 30-31 m OD; iv) the deposits within all the facies associations fine down530 current, from ice-proximal to ice-distal environment (from the north to the south). Features 531 unique to the the Stanway Quarry comprise: i) a south-west to north-east aligned erosional 532 depression in the London Clay surface filled by crudely horizontally, trough cross- to solitary 533 planar cross-bedded clast and matrix-supported gravel of facies association G1; ii) facies 534 association F1 consisting of recurrent successions of normally graded sand, silt and clay and 535 stiff, massive clay and silt. Two typical features are present only in the Birch Quarry: i) 536 deformed sand facies association S1 and ii) the massive structureless diamicton of facies 537 association D1. As mentioned above, the succession in the Birch-Stanway area was 538 previously interpreted as being of glacial (Bell 1985; Bailey 1996), fluvial (proto-Thames 539 origin, Arditto 1995) and of partly glacial, partly fluvial origin (Bristow \& Lake 1975; 540 Bristow 1985; Ellison \& Lake 1986).

541 Some of the characteristics of gravel unit G1, such as: i) the alignment of the channel 542 in a south-west to north-east line; ii) the palaeocurrent direction towards the north-east 543 indicated by sedimentary structures within exposures; iii) the altitude of deposits (between 1354415 to $17.5-18 \mathrm{~m} \mathrm{OD})$ and iv) the presence of lithologies characteristic of the Kesgrave 545 Formation (quartz, quartzite, sandstone, pinhole and Greensand chert), coincide with 546 characteristics predicted for the proto-Thames river and its deposits in this area (Gibbard 547 1995). However, at the same time gravelly facies association G1 including (i) a high 548 percentage of the typical Lowestoft Formation lithologies (mainly angular flint); (ii) the 549 pebble to cobble size of gravel; (iii) the presence of clay intraclasts derived from the 550 underlying London Clay, and iv) poor sorting, closely resemble sediments deposited by the 551 Anglian ice sheet meltwater. Following from this, the gravel of facies association G1 is 552 interpreted as being deposited by meltwater, which flowed through the channel previously 
553 occupied by the pre-existing River Thames (Figs. 1B, 9A). Sedimentary features interpreted

554 as deposited from traction, as a bedload lag, within longitudinal bars or minor channels

555 indicate deposition within the braided river environment of the ice-proximal setting. At the 556 initial stage of the Anglian glaciation, this channel became the main evacuation route for the 557 glacial meltwater. The pre-existing Kesgrave Formation gravel, including material exotic to 558 the area, was remobilised. Reworked clasts were diluted within the lithological components 559 transported by the meltwater of the Anglian ice sheet and re-deposited in the Birch-Stanway 560 area.

561 With time, as the Anglian ice sheet advanced closer to the Birch-Stanway area, the 562 channel could no longer evacuate the excessive amount of meltwater. The water associated 563 with the Anglian ice sheet began to flow across the valley towards the south-east and south, as 564 predicted for the meltwater in this part of England (Fig. 9B). It deposited overlying sediments 565 of facies association G2, S1 and F1. The lithological characteristics of this succession (mainly 566 G2 and S1), i.e. the presence of clasts characteristic of the fluvial proto-Thames formation 567 (quartz, quartzite, sandstone, pinchole and greensand chert) among lithological components 568 typical of glacial affinities (flint, mainly angular), confirm that the deposits of the Kesgrave 569 Formation gravel were reworked and re-deposited by water associated with the Anglian ice 570 sheet. A similar view was proposed for the interpretation of the sand and gravel deposits from 571 other areas of eastern England by Wood (1868), Clayton (1957), Bristow \& Cox (1973) and 572 Whiteman et al. (1995), including the Banham Sand and Gravel Member (glacigenic deposits 573 described in the area north-west of Diss in Norfolk) by Mathers et al. (1987).

574 While considering various types of sedimentary environments within the pro-glacial 575 domain, the Birch-Stanway succession shares many characteristics with an extensive 576 subaqueous fan or a series of coalescing subaqueous fans and deltaic deposits within a 577 glaciolacustrine setting (Ashley \& Smith 1985; Winsemann et al. 2009; Lang \& Winsemann 
578 2013). This interpretation partially supports the glacial interpretations previously advocated 579 by Bell (1985) and Bailey (1996). The units of gravel G2, described from the northern and 580 north-western parts of Birch and Stanway quarries, are the product of maximum sediment 581 transfer in a gravel-dominated environment deposited close to the source area (ice margin), 582 i.e. an ice-proximal setting (Miall 1977; Reineck \& Singh 1980; Miall 1985; Smith 1985; 583 Benn \& Evans 2002). These sediments are dominated by highly aggradational supercritical 584 flow, sheetflow, debris flow and traction deposits, but lacking easily identifiable channels and 585 erosional surfaces (Blair \& McPherson 1994). These features, together with the coarse and 586 massive character of these deposits, indicate their deposition occurred during catastrophic 587 floods. In the case of a pro-glacial setting, this type of event is associated with phases of peak 588 meltwater discharge directly from the ice-masses or from beneath them (Rust \& Romanelli 589 1975; Winsemann et al. 2009).

590 The gradational change from the north and north-west to the south and south-east, 591 from gravel-dominated to sand-dominated deposits (from facies association G2 to S1) 592 represents a progressive change from an ice-proximal to an ice-distal environment within the 593 subaqueous fan setting. This area is characterised by a lateral flow transition associated with a 594 decrease in flow competency and decline in sediment load. The lateral and the upward fining 595 of the sediments from gravelly to sandy deposits is associated with the flow splitting at the 596 mouth of the conduit(Winsemann et al. 2009; Lang \& Winsemann 2013). The dominant well597 developed cross-, trough cross-bedded and planar parallel-bedded sandy deposits of the upper 598 portions of the facies association S1, are associated with large-scale, unconfined, migrating 599 bedforms (dunes) - typical for the zone of established flow in a subaqueous fan setting (Lang 600 \& Winsemann 2013).

601 The two main levels of gravel and sand deposits in the Birch-Stanway area, divided by 602 erosional surface ES at 30-31 m OD, associated with periglacial conditions, represent two 
603 main depositional events separated by a period of quiescence. The deposition of both units of

604 G2 is interpreted as evidence for enhanced sediment transfer associated with intense ablation, 605 interpreted as being caused by the retreat of the ice margin. As the meltwater within the ice606 domain is transported via sub-, en- and supra-glacial conduits for long distances, its retreat 607 and loss of ice-mass may not necessarily directly affect the closest vicinity of the Birch 608 Stanway area, but may be of a more regional or distant local scale. The non-depositional 609 event/hiatus in a pro-glacial environment may indicate halted ablation arising from 610 deteriorating climatic conditions, as well as the associated standstill of the ice margin or even 611 its advance (Smith 1985). The presence of periglacial features (ice-wedge casts within 612 gravelly units G2), associated inherently with the subaerial exposure is also the evidence for 613 the absence of glaciolacustrine conditions, following from the temporal, partial lake drainage. 614 The lake drainage may be associated with palaeogeographical changes elsewhere or a 615 negative drainage/inflow ratio - with dominance of drainage on inflow.

616 The direct evidence for a glaciolacustrine environment in the Birch-Stanway area is 617 represented by fine deposits of sand, silt and clay of facies association F1 at the southernmost 618 part of Stanway Quarry. The evidence for the close proximity of the ice-front to the Birch619 Stanway area is present in the form of diamicton facies association D1. It is interpreted as 620 having been deposited by the glacial ice and marks the southern and south-easternmost extent 621 of the ice sheet in this area. The deformation structures within the underlying S1, indicate 622 stress from the north-west, what is presumed direction of the ice-sheet advance in this part of 623 East Anglia (Allen et al. 1991).

624 The absence of reworked glacial debris within the succession described from the 625 Birch-Stanway area are atypical of subaqueous fans. This may be caused by i) the shallow 626 water depth into which the meltwater deposited the gravel and sand and/or ii) an excessive 
627 amount of sediment transported by meltwater which were distributed evenly in the pro-glacial 628 zone.

The subaqueous fan described from the Birch-Stanway area is interpreted to have been 630 aggraded by a conduit-focused sedimentation (Fyfe 1990). The main source of meltwater is

631 likely to have been a deep channel ('tunnel valley') cut within the London Clay on the north632 western slopes of the Danbury-Tiptree ridge, to the south-west of the Birch-Stanway area 633 (Bristow \& Lake 1975; Bristow 1985) (Fig. 1D). The meltwater evacuated from the Anglian 634 ice-sheet margin could not escape towards the south-east since that direction was blocked by 635 the ridge. The lateral ice-marginal drainage was therefore deflected towards the north-east, 636 parallel to the topographical barrier. At the north-eastern end of the ridge, meltwater was able 637 to escape via the Birch-Stanway area portal, depositing substantial volumes of sand and 638 gravel as a proglacial subaqueous fan system. The slightly variable palaeocurrent directions, 639 with all generally trending towards the south-east, is caused by the flow splitting at the 640 conduit mouth during fan aggradation(Winsemann et al. 2009) or less likely variable position 641 of the water supply associated with multiple sub-glacial outlets (portals, conduits) separate 642 for the Birch and Stanway quarry areas.

\section{A regional perspective}

644 The Birch-Stanway subaqueous fan complex was an ice-marginal meltwater evacuation route, 645 which initially adopted the pre-existing course of the pre-diversion River Thames to some 646 extent. The geographical situation of the Birch-Stanway subaqueous fan system, in the south647 eastern part of East Anglia, implies that it potentially formed a linkage between the Anglian 648 ice sheet margin and the lake formed by the ponding of pro-glacial waters by the ice sheet in 649 the southern North Sea basin, as noted by Gibbard (1988, 1995, 2007) and Cohen et al. (2005) 650 (Fig. 1A). These authors suggest that at its maximum, the water level of the lake reached $\sim 30$ $651 \mathrm{~m}$ OD at the Dover Straits col; Gibbard \& van der Vegt (2012) also confirm that levels in 
652 excess of $32 \mathrm{~m}$ are represented in northern East Anglia (Corton Member sediments).

653 Following from this, the deposits of unit F1 at Stanway Quarry, interpreted as glaciolacustrine 654 accumulation, occuring at the 30-31 m OD, intermediate between two discrete pulses of the 655 sand and gravel deposition, may be direct evidence of the presence of the North Sea lake in 656 this locality. The correspondence of these levels to those of the North Sea lake implies that it 657 is likely that the Birch-Stanway subaqueous fan aggraded directly into this water body.

658 The conclusion that the Anglian ice-marginal zone was in direct contact with the 659 contemporary North Sea lake in the Birch-Stanway area, as suggested by the sedimentology 660 and elevation of the glaciolacustrine sediments within Stanway Quarry, represents an exciting 661 opportunity for further detailed study of this proglacial system. The fruits of these studies 662 would resolve some of the complexities arising from the correlation between the British and 663 north-European successions and would contribute further to large-scale reconstructions of 664 palaeogeographical evolution, including changes in water-level, isostatic adjustments, and 665 erosion and deposition, through the Anglian/Elsterian glaciation (Gibbard 1988, 1995; 666 Moreau \& Huuse 2013). So far, attempts to link fine-grained deposits from the Birch-Stanway 667 area with those of the North Sea lake by clay mineralogical analysis have confirmed the 668 overwhelming influence of the background signal within the samples (Leszczynska et al., 669 2010). The mineralogical composition of the clay samples from the Birch-Stanway area, 670 which were dominated by mica (illite) with a mixed-layer micaceous smectite and minor 671 kaolinite, has also been observed in analyses from other sites in East Anglia: from Aldeburgh 672 in Suffolk (Huggett \& Knox 2006) and the Dengie Peninsula in Essex(Gibbard et al. 1996). 673 The mineralogical composition of all these samples is associated with the London Clay that 674 underlies the succession in southern East Anglia.

675 Stratigraphical correlations 
676 Based on the i) general sedimentary and lithological characteristics; ii) the topographical 677 altitude of the units and, most importantly, iii) the relationship of these units to the erosional 678 boundary at $30-31 \mathrm{~m} \mathrm{OD}$ at both sites, it is proposed that a relationship exists between Birch 679 and Stanway quarries with regard to their sand and gravel deposits. It is suggested that the 680 sand and gravel units of G2 and S1 below the 30-31 m OD level at Stanway Quarry are a 681 counterpart of the sand and gravel deposits of G1 and S1 below that level at Birch Quarry. 682 The lithostratigraphical term 'Birch-Stanway Lower Sand and Gravel' is proposed for this 683 unit. Similarly the sand and gravel deposits overlying the 30-31 m OD boundary, namely the 684 upper unit of G2 at Stanway Quarry and the uppermost unit of G2 at Birch Quarry, are 685 correlated on the same basis to be the 'Birch-Stanway Upper Sand and Gravel'. They are 686 interpreted to represent two discrete depositional events associated with enhanced meltwater 687 release and possibly the retreat of the Anglian ice sheet and associated partial lake drainage 688 and subaerial exposure of the deposits (periglacial features). These deposits are therefore 689 members of the Lowesoft Formation (Bristow 1985).

690 The basal gravel described from the Stanway Quarry, which differs sedimentologically 691 and lithologically from all the overlying deposits, is proposed to represent a separate unit, 692 named hereafter the 'Stanway Basal Gravel'. It represents the final course of the lower 693 reaches of the proto-Thames River before the diversion to its current position and after the 694 onset of the Anglian glaciation in East Anglia. On the basis of similar lithological properties, 695 the altitude, and its tentative/stratigraphical chronology, the Stanway Basal Gravel is proposed 696 as a counterpart of the Hertfordshire Westmill Gravel, the youngest member of the Kesgrave 697 Formation (Gibbard 1977).

\section{Conclusions}

699 - This investigation of a 15-20 m thick succession of well-preserved Middle Pleistocene 700 deposits in the Birch-Stanway area represents an important opportunity at the scale of 
701 north-western Europe to reconstruct the palaeoenvironmental conditions and character 702 of the ice margin at the Anglian ice sheet periphery within the European context. The 703 main results are summarized below. The sedimentary succession described from the 704 Birch-Stanway area, East Anglia, consists of major units of laterally extensive gravelly 705 deposits dissected by an erosional boundary or a non-depositional event. They are 706 interbedded with sandy facies associations and grade into sandy deposits laterally, in a 707 down-current direction, from an ice-proximal to an ice-distal environment, from the 708 north to the south. In the northern and north-western part of the area they are capped 709 with deformed sand and diamicton, while in the south there is a unit of fine-grained 710 deposits inserted between sand and the upper unit of gravel.

711 - The depositional palaeoenvironment of sand and gravel in the Birch-Stanway area 712 consists of two or more, laterally overlapping subaqueous fan features. Palaeocurrent 713 trends from the north and north-west towards the south and south-east indicate a 714 direction of flow from the ice sheet margin towards the proglacial zone. The fining 715 trend in particle size from the north and north-west towards the south and south-east 716 indicates the change of depositional sub-environments from proximal to distal, 717 respectively. The presence of glacial damicton capping the succession indicates the 718 proximity of the ice sheet margin. The break in sedimentation dividing the deposits 719 into two separate successions indicates at least two cycles of evolution of the system.

720 - The location of substantially thick sand and gravel successions at Birch-Stanway area 721 was determined by a) the excessive amount of sand and gravel transported from the 722 area where deposition in the pro-glacial zone was restricted by topographical 723 obstruction, the Danbury-Tiptree ridge; b) the presence of accommodation space 724 associated with the transition from a constrained to an unconstrained ice-front and c) 725 the pre-existing proto-Thames river channel. It was the presence of the extensive 
Danbury-Tiptree topographical ridge, protruding towards the south-west of the BirchStanway area and blocking the passage of the Anglian ice sheet and its meltwater, that created a unique set of topographical conditions for the deposition of glacial sediments in this locality. In the case of a freely flowing ice margin, the meltwater sediments would only create a flat outwash plain, in the whole length of the pro-glacial zone. an excessive amount of meltwater was flowing across the channel towards south and

- The proto-Thames early Anglian course towards the east, described from BirchStanway area (Stanway Basal Gravel at Stanway Quarry) has been established as an initial evacuation route for the meltwater from the pro-glacial zone. When the Anglian ice sheet advanced closer to the Birch-Stanway area, the channel was abandoned and south-east. Pre-existing river deposits supplied the material, which was later reworked and deposited together with sediments associated with the Anglian ice sheet within the ice-contact fan succession.

- The Birch-Stanway subaqueous fan complex is evidence for the position of the Anglian ice sheet margin in this part of East Anglia. It has not been overridden by a subsequent glaciation and it marks the southernmost reach of the ice sheet. The fan succession indicates fluctuations of the ice front associated with at least two periods of enhanced meltwater release and following from that, possibly ablation and retreat, as well as possible partial lake drainage.

- Fine-grained facies F1 in the southern part of the Stanway Quarry, on the basis of sedimentary characteristics as well as the altitude, is interpreted as glaciolacustrine deposits, which may be, together with the subaqueous fan, contemporaneous to the glacial lake in the North Sea Basin. This proposal remains to be further confirmed.

Acknowledgments. KL thanks and acknowledges the support of Philip Hughes, Chris Jeans, Chris Rolfe, Philip Stickler, Paul and Helena van der Vegt and Robert Leszczynski during this 
751 challenging research project. Also special thanks to Grzegorz Adamiec (the GADAM Centre)

752 as well as Emma Good, Paul Joel and the Tarmac PLC team. This project was financially

753 supported by the Quaternary Research Association, Cambridge Philosophical Society, British

754 Society for Geomorphology and Department of Geography, University of Cambridge. The

755 authors thank two Reviewers for throughout reviews and constructive comments. .

756 
757 Alexander, J., Bridge, J. S., Cheel, R. J. \& Leclair, S. F. 2001: Bedforms and associated 758 sedimentary structures formed under supercritical water flows over aggrading sand 759 beds. Sedimentology 48, 133-152.

760 Allen, P., Chesshire, D. A. \& Whiteman, C. A. 1991: The tills of southern East Anglia. In 761 Ehlers, J., Gibbard, P. L. \& Rose, J. (eds.): Glacial deposits in Great Britain and 762 Ireland, 255-278. A. A. Balkema, Rotterdam-Brookfield.

763 Ambrose, J. D. 1973: The sand and gravel resources of the country around Maldon, Essex. 764 Description of 1:25 000 resources sheet TL 80. Assessment of British Sand and Gravel 765 resources 4. 67 pp. Natural Environmental Research Council, Institute of Geological 766 Sciences, London.

767 Ambrose, J. D. 1974: The sand and gravel resources of the country west of Colchester, Essex. 768 Description of 1:25 000 resource sheet TL 92. Assessment of British Sand and Gravel 769 Resources 10. Natural Environmental Research Council, Institute of Geological $770 \quad$ Sciences, London.

771 Ambrose, J. D. 1975: Sand and gravel resources of the country east of Colchester. 772 Description of 1:25 000 resource sheet TM 02. Mineral Assessment Report 14. 33 pp. 773 Her Majesty's Stationery Office, London.

774 Arditto, C. S. 1995: Geological investigation of the Bellhouse sand pit, Colchester, Essex. Site 775 Exploration Report. 87 pp. unpublished, Colchester.

776 Ashley, G., Southard, J. B. \& Boothroyd, J. C. 1982: Deposition of climbing-ripple beds: a 777 flume simulation. Sedimentology 29, 67-79.

778 Ashley, G. M. \& Smith, N. D. 1985: Proglacial lacustrine environment. In Ashley, G. M., 779 Shaw, J. \& Smith, A. M. (eds.): Glacial sedimentary environments. Society of 780 Economic Palaeontologists and Mineralogists Short Course No. 16, 22-101. Society 781 of Palaeontologists and Mineralogists, Tulsa. 
782 Bailey, E. P. 1995: Report on geological exploration carried out at Fiveways Fruit Farm,

783 Stanway, Colchester. Site Exploration Report. 113 pp. unpublished, Colchester.

784 Bailey, E. P. 1996: Report on geological exploration carried out at Bellhouse Farm, $785 \quad$ Abbotstone. 113 pp. unpublished, Colchester.

786 Banham, P. H. 1970: North Norfolk. In Boulton, G. S. (ed.): East Anglia Field Guide, 11-17.

787 Quaternary Research Association, London.

788 Banham, P. H. 1988: Polyphase glaciotectonic deformation in the Contorted Drift of Norfolk.

789 In Croot, D. G. (ed.): Glaciotectonics: Forms and Processes, 27-32. Balkema, $790 \quad$ Rotterdam.

791 Bell, A. 1985: Report on the geology, reserves and hydrogeology of Bellhouse/Colchester 792 sand pits and associated landholders. Site Exploration Report. 57 pp. unpublished, 793 Colchester.

794 Benn, D. I. \& Evans, D. J. A. 2002: Glaciers and glaciations. 734 pp. Edward Arnold, 795 London.

796 Bennett, M. R., Huddart, D. \& Thomas, G. S. P. 2002: Facies architecture within a regional 797 glaciolacustrine basin: Copper River, Alaska. Quaternary Science Reviews 21, 223722798.

799 Beres, M., Green, A., Huggenberger, P. \& Horstmeyer, H. 1995: Mapping the architecture of 800 glaciofluvial sediments with three-dimensional georadar. Geology 23, 1087-1090.

801 Blair, T. C. \& McPherson, J. G. 1994: Alluvial fans and their natural distinction from rivers 802 based on morphology, hydraulic processes, sedimentary processes, and facies 803 assemblages. Journal of Sedimentary Research 64, 450-489.

804 Boothroyd, J. C. \& Ashley, G. M. 1975: Process, bar morphology and sedimentary structures 805 on braided outwash fans, North-eastern Gulf of Alaska. In Jopling, A. V. \& 
806 McDonald, B. C. (eds.): Glaciofluvial and Glaciolacustrine Sedimentation, 193-222.

807 Society of Economic Palaeontologists and Mineralogists, Tulsa.

808 Bridgland, D. R. 1983a: Eastern Essex. In Rose, J. (ed.): Quaternary Research Association 809 Field Guide: Diversion of the Thames, 170-180. Quaternary Research Association, $810 \quad$ London.

811 Bridgland, D. R. 1983b: The rudaceous components of the East Essex Gravel; their 812 characteristic and provenance. Quaternary Studies 2, 34-44.

813 Bridgland, D. R. 1986: Clast lithological analysis. 207 pp. Quaternary Research Association, $814 \quad$ Cambridge.

815 Bridgland, D. R. 1988: The Pleistocene fluvial stratigraphy and palaeogeography of Essex. 816 Proceedings of the Geologists' Association 99, 291-314.

817 Bristow, C. R. 1985: Geology of the country around Chelmsford. 108 pp. Natural 818 Environmental Research Council, Her Majesty's Stationery Office, London.

819 Bristow, C. R. \& Cox, F. C. 1973: The Gipping Till: a reappraisal of East Anglia glacial 820 stratigraphy. Journal of the Geological Society of London 129, 1-37.

821 Bristow, C. R. \& Lake, D. R. 1975: Geology Map - Solid and Drift, Sheet 241 (Chelmsford). 822 British Geological Survey, England and Wales.

823 Cartigny, M. J. B., Ventra, D., Postma, G. \& Van Den Berg, J. H. 2012: Morphodynamics and 824 sedimentary structures of bedforms under supercritical-flow conditions: New insights 825 from flume experiments. Sedimentology 61, 712-748.

826 Church, M. \& Gilbert, R. 1975: Proglacial Fluvial and Lacustrine Environments. In Jopling, 827 A. V. \& McDonald, B. C. (eds.): Glaciofluvial and Glaciolacustrine Sedimentation, 828 22-101. Society of Economic Palaeontologists and Mineralogists, Tulsa.

829 Clayton, K. M. 1957: Field Meeting at Danbury Hill, near Chelmsford, Essex. Proceedings of 830 the Geologists' Association 68, 22-26. 
831 Clemmensen, L. B. \& Houmark-Nielsen, M. 1981: Sedimentary features of a Weichselian 832 glaciolacustrine delta. Boreas 10, 229-245.

833 Cohen, K. M., Busschers, F. S. \& Gibbard, P. L. 2005: Stratigraphical implications of an 834 Elsterian pro-glacial 'North Sea' lake. Abstract. In Dehner, A. \& Preusser, F. (eds.): 835 Subcomission of European Quaternary Stratigraphy 2005 Annual Meeting, 22. SEQS, $836 \quad$ Bern, Switzerland.

837 Cohen, K. M., Gibbard, P. L. \& Busschers, F. S. 2008: Middle Pleistocene ice lake high 838 stands in the Northern Sea: how do they change regional stratigraphical frameworks? 839 Abstract. In Monnier, J.-L., Lefort, J.-P. \& Danukalova, G. (eds.): INQUA-SEQS 2008 $840 \quad$ Conference Abstract Book, 13. INQUA-SEQS, Rennes, France.

841 Collinson, J. D. \& Thompson, D. B. 1989: Sedimentary structures. 194 pp. Allen \& Unwin, $842 \quad$ London.

843 Duller, R. A., Mountney, N. P., Russel, A. J. \& Cassidy, N. C. 2008: Architectural analysis of 844 a volcaniclastic jokulhlaup deposit, southern Iceland: Sedimentary evidence for $845 \quad$ supercritical flow. Sedimentology 55, 939-964.

846 Ehlers, J., Grube, A., Stephan, H.-J. \& Wanse, S. 2011: Pleistocene Glaciations of North 847 Germany - New Results. In Ehlers, J., Gibbard, P. \& Hughes, P. (eds.): Developments 848 in Quaternary Science, 149-162. Elsevier, Rotterdam.

849 Ellison, R. A. \& Lake, R. D. 1986: Geology of the country around Braintree. Memoir for 1:50 $850 \quad 000$ geological sheet 223 (England and Wales). 80 pp. Natural Environmental 851 Research Council. Her Majesty's Stationery Office, London.

852 Evans, D. J. A. \& Benn, D. I. 2004: A practical guide to the study of glacial sediments. 266 853 pp. Edward Arnolds, London. 
854 Eyles, N., Eyles, C. H. \& McCabe, A. M. 1989: Sedimentation in an ice-contact subaqueous 855 setting: the id-Pleistocene 'North Sea Drift' of Norfolk, UK. Quaternary Science $856 \quad$ Reviews $8,57-74$.

857 Eyles, N., Eyles, C. H. \& Miall, A. D. 1983: Lithofacies types and vertical profiles models. 858 An alternative approach to the description and environmental interpretation of glacial 859 diamict and diamictite sequences. Sedimentology 30, 393-410.

860 Fielding, C. R. 2006: Upper flow regime sheets, lenses and scour fills: Extending the range of 861 architectural elements for fluvial sediment bodies. Sedimentary Geology 190, 227-240.

862 Fyfe, G. J. 1990: The effect of water depth on ice--proximal glacilacustrine sedimentation: 863 Salpausselka I, southern Finland. Boreas 19, 147-164.

864 Gawthorpe, R. L., Li Collier, R. E., Alexander, J., Bridge, J. S. \& Leeder, M. R. 1993:

865 Ground penetrating radar: application to sandbody geometry and heterogeneity 866 studies. Geological Society of London, Special Report 73, 421-432.

867 Gibbard, P. 1980: The origin of stratified CatfishCreek Till by basal melting. Boreas 9, 71-85.

868 Gibbard, P. L. 1977: Pleistocene history of the Vale St. Albans. Philosophical Transactions of 869 the Royal Society of London, series B 280, 445-483.

870 Gibbard, P. L. 1988: The history of the great northwest European rivers during the last three 871 million years. Philosophical Transactions of the Royal Society of London B318, 559872602.

873 Gibbard, P. L. 1995: Formation of Strait of Dover. In Preece, R. C. (ed.): Island Britain - $a$ 874 Quaternary perspective, 15-26. Geological Society of London, London.

875 Gibbard, P. L. 2007: Europe cut adrift. Nature 448, 259-260.

876 Gibbard, P. L., Aalto, M. M., Coope, R. G., Currant, A. P., McGlade, J. M., Peglar, S. M., 877 Preece, R. C., Turner, C. \& Whiteman, C. A. 1996: Early Middle Pleistocene 


\begin{abstract}
878 fossiliferous sediments in the Kesgrave Formation at Broomfield, Essex, England. In Turner, C. (ed.): The Early Middle Pleistocene in Europe. A. A. Balkema, Rotterdam.

880 Gibbard, P. L. \& Allen, L. G. 1994: Drainage evlolution in south and east England during the 881 Pleistocene. Terra Nova 6, 444-452.
\end{abstract}

882 Gibbard, P. L. \& van der Vegt, P. 2012: The genesis and significance of the Middle 883 Pleistocene glacial meltwater and associated deposits, East Anglia. In Dixon, R. \& 884 Markham, C. B. (eds.): The geology of Suffolk (GoeSuffolk 10th Anniversary Volume), 885 303-326. GeoSuffolk, Ipswich.

886 Gibbard, P. L. \& Zalasiewicz, J. A. 1988: Pliocene - Middle Pleistocene of East Anglia. Field 887 Guide. Quaternary Research Association, Cambridge.

888 Glanville, C. 1997: Glaciolacustrine and glaciofluvial deposits defining the margins of 889 uncoupling ice lobes in the Southeastern Midlands of Ireland. Quaternary Science $890 \quad$ Reviews $16,685-703$.

891 Green, C. P., Hey, R. W. \& McGregor, D. F. M. 1980: Volcanic pebbles in Pleistocene 892 gravels of the Thames in Buckinghamshire and Hertfordshire. Geological Magazine $893 \quad 117,59-64$.

894 Green, C. P. \& McGregor, D. F. M. 1978: Pleistocene gravel trains of the River Thames. 895 Proceedings of the Geologists' Association 89, 143-156.

896 Green, C. P., McGregor, D. F. M. \& Evans, A. H. 1982: Development of the Thames drainage 897 system in Early and Middle Pleistocene times. Geological Magazine 119, 281-290.

898 Gupta, S., Collier, J. S., Palmer-Felgate, A. \& Potter, G. 2007: Catastrphic flooding origin of 899 shelf valleysystem in English Channel. Nature 448, 342-345.

900 Hart, J. K. 1992: Sedimentary environments associated with glacial lake Trimingham, $901 \quad$ Norfolk, UK. Boreas 21, 119-136. 
902 Hart, J. K. 1994: Till fabrics associated with deformable beds. Earth Surface Processes and 903 Landforms 19, 15-32.

904 Hey, R. W. 1965: Highly quartzose pebble gravels in the London Basin. Proceedings of the 905 Geologists' Association 76, 403-420.

906 Hey, R. W. 1976: Provenance of far travelled pebbles in the pre-Anglian Pleistocene of East 907 Anglia. Proceedings of the Geologists' Association 87, 69-81.

908 Hey, R. W. 1980: Equivalents of the Westland Green Gravels in Essex and East Anglia. $909 \quad$ Proceedings of the Geologists' Association 91, 279-290.

910 Hey, R. W. \& Brenchley, P. J. 1977: Volcanic pebbles from Pleistocene gravels in Norfolk 911 and Essex. Geological Magazine 114, 219-225.

912 Huggett, J. M. \& Knox, R. W. O. B. 2006: Clay mineralogy of the Tertiary onshore and 913 offshore strata of the British Isles. Clay minerals 41, 5-46.

914 Jones, A. P., Tucker, M. E. \& Hart, J. K. 1999: The description and analysis of Quaternary 915 stratigraphic sections. 293 pp. Quaternary Research Association, London.

916 Jopling, A. V. \& Walker, R. G. 1968: Morphology and origins of ripple-drift cross lamination 917 with examples from the Pleistocene of Massachusetts. Journal of Sedimentary $918 \quad$ Research 38, 971-984.

919 Kazi, A. \& Knill, J. L. 1969: The sedimentation and geotechnical properties of the Cromer 920 Till between Happisburgh and Cromer, Norfolk. Quarterly Journal of Engineering $921 \quad$ Geology 2, 63-86.

922 Krumbein, W. C. 1937: Sediments and expotential curves. Journal of Geology 45, 577-601.

923 Krumbein, W. C. \& Pettijohn, F. J. 1938: Manual of sedimentary petrography. 128 pp. 924 Appleton-Century-Crofts, Inc., New York.

925 Krzyszkowski, D. \& Zielinski, T. 2002: The Pleistocene end moraine fans: controls on their 926 sedimentation and location. Sedimentary Geology 149, 73-92. 
927 Laban, C. \& van der Meer, J. J. M. 2011: Pleistocene Glaciation in the Netherlands. In Ehlers, 928 J., Gibbard, P. \& Hughes, P. D. M. (eds.): Quaternary Glaciaitons - Extent and 929 Chronology. A closer look., 247-260. Elsevier, Amsterdam.

930 Lang, J. \& Winsemann, J. 2013: Lateral and vertical facies relationships of bedforms 931 deposited by aggrading supercritical flows: from cyclic steps to humpback dunes. 932 Sedimentary Geology 296, 36-54.

933 Lucy, G. 1999: Essex rock: a look beneath the Essex landscape. 128 pp. Essex Rock and 934 Mineral Society, Colchester.

935 Lunkka, J. P. 1988: Sedimentation and deformation of the North Sea Drift Formation in the 936 Happisburgh area, North Norfolk. In Croot, D. G. (ed.): Glaciotectonics: Forms and 937 Processes, 109-122. Balkema, Rotterdam.

938 Lunkka, J. P. 1991: Sedimentology of the Anglian Glacial Deposits in Northeast Norfolk, 939 England. PhD Thesis. University of Cambridge, Cambridge.

940 Lunkka, J. P. 1994: Sedimentology and lithostratigraphy of the North Sea Drift and Lowestoft 941 Till Formations in the coastal cliffs of NE Norfolk. Journal of Quaternary Science 9, 942 209-234.

943 Maizels, J. 1993: Lithofacies variations within sandur deposits: the role of runoff regime, flow 944 dynamics and sediment supply characteristics. Sedimentary Geology 85, 299-325.

945 Maizels, J. 1997: Jökulhlaup deposits in proglacial areas. Quaternary Science Reviews 16, $946 \quad 793-819$.

947 Marren, P. M. 2001: Sedimentology of proglacial rivers in eastern Scotland during the Late 948 Devensian. Transactions of the Royal Society of Edinburgh, Earth Sciences 92, 149$949 \quad 171$.

950 Massari, F. 1996: Upper-flow-regime stratification types on steep-face, coarse-grained, 951 Gilbert-type progradational wedges. Journal of Sedimentary Research 66, 364-375. 
952 Mathers, S. J., Zalasiewicz, J. A. \& Bloodworth, A. J. 1987: The Banham Beds: a 953 petrologically disticnt suite of Anglian glacigenic deposits from central East Anglia. 954 Proceedings of the Geologists' Association 98, 229-240.

955 McGregor, D. F. M. \& Green, C. P. 1986: Early and Middle Pleistocene gravel deposits of the 956 Thames - development of a lithostratigraphical model. In Bridgland, D. R. (ed.): 957 Quaternary Research Association Technical Guide. Clast lithological Analysis, 95958 116. Quaternary Research Association, Cambridge.

959 Miall, A. D. 1977: A review of braided river depositional environment. Earth Science Review $960 \quad 13,1-62$.

961 Miall, A. D. 1978: Lithofacies types and vertical profile models in braided river deposits: a 962 summary. In Miall, A. D. (ed.): Fluvial Sedimentology, 597-604. Canadian Society of 963 Petrological Geology, Calgary.

964 Miall, A. D. 1985: Architectural-element analysis: a new method of facies analysis applied to 965 fluvial deposits. Earth Science Review 22, 261-308.

966 Moreau, J. \& Huuse, M. 2013: Infill of tunnel valleys associated with landward-flowing ice967 sheets: The missing Middle Pleistocene record of the NW European rivers? 968 Geochemistry, Geophysics, Geosystems 14, 1-9.

969 Mulder, T. \& Alexander, J. 2001: The physical character of subaqueous sedimentary density $970 \quad$ flows and their deposits. Sedimentology 48, 269-299.

971 Neal, A. 2004: Ground-penetrating radar and its use in sedimentology: principles, problems $972 \quad$ and progress. Earth Science Reviews 66, 261-330.

973 Plink-Bjorklund, P. \& Ronnert, L. 1999: Depositional processes and internal architecture of 974 Late Weichselian ice-marginal submarine fan and delta settings, Swedish west coast. 975 Sedimentology 46, 215-234. 
976 Postma, G. 1986: Classification for sediment gravity flow deposits based on flow conditions 977 during sedimentation. Geology 14, 291-294.

978 Regli, C., Huggenberger, P. \& Rauber, M. 2002: Interpretation of drill core and georadar data 979 of coarse gravel deposits. Journal of Hydrology 255, 234-252.

980 Reineck, H.-E. \& Singh, I. B. 1980: Depositional Sedimentary Environments. 551 pp. $981 \quad$ Springer-Verlag, Berlin - Heidelberg.

982 Roep, T. B., Holst, H., Vissers, R. L. M., Pagnier, H. \& Postma, D. 1975: Deposits of 983 southwardflowing, Pleistocene rivers in the Channel Region, near Wissant, NW 984 France. Palaeogeography, Palaeoclimatology, Palaeoecology 17, 289-308.

985 Russell, H. A. J. \& Arnott, R. W. C. 2003: Hydraulic-jump and hyperconcentrated flow 986 deposits of a glacigenic subaqueous fan: Oak Ridge moraine, southern Ontario, 987 Canada. Journal of Sedimentary Research 73, 887-905.

988 Rust, B. R. \& Romanelli, R. 1975: Late Quaternary subaquous outwash deposits near Ottawa, 989 Canada. In Jopling, A. V. \& McDonald, B. C. (eds.): Glaciofluvial and 990 Glaciolacustrine Sedimentation, 177-192. Society of Economic Palaeontologists and $991 \quad$ Mineralogists, Tulsa.

992 Shanmugam, G. 2000: 50 years of the turbidite paradigm (1950s-1990): deep-water processes 993 and facies models - a critical perspective. Marine Petrology and Geology 17, 285-273. 994 Smith, A. M. 1985: Proglacial fluvial environment. In Ashley, G., Shaw, J. \& Smith, A. M. 995 (eds.): Glacial Sedimentary Environments, Short Course, 135-207. Society of 996 Economic Palaeontologists and Mineralogists, Tulsa.

997 Stackebrandt, W. 2009: Subglacial channels of Northern Germany - a brief review. Zeitschrift 998 der Deutschen Gesellschaft fur Geowissenschaften 160, 203-210.

999 Toucanne, S., Zaragosi, S., Bourillet, J. F., Cremer, M., Eynaud, F., Turon, J. L., Cortijo, E. \& 1000 Gibbard, P. L. 2009a: Timing of massive 'Fleuve Manche' discharges over the last 350 
1001 kyr: insight into the European Ice Sheet oscillations and the European drainage 1002 network from MIS 10 to 2. Quaternary Science Reviews 28, 1238-1256.

1003 Toucanne, S., Zaragosi, S., Burillet, J. F., Gibbard, P., Eynaud, F. \& Giraudeau, J. 2009b: A 1004 1.2 Ma record of glaciation and fluvial discharge from the West European Atlantic 1005 margin. Quaternary Science Reviews 28, 2974-2981.

1006 Tucker, M. 2006: Sedimentary Rocks in the field. 234 pp. John Wiley \& Sons, Chichester.

1007 Whiteman, C. A., Bridgland, D. R., Allen, P. \& Cheshire, D. A. 1995: Maldon cutting. In 1008 Bridgland, D. R., Allen, P. \& Haggard, C. (eds.): The Quaternary of the lower reaches 1009 of the Thames. Field guide, 247-254. Quaternary Reseach Association, London.

1010 Winsemann, J., Hornung, J. J., Mainsen, J., Asprion, U., Polom, U., Brandes, C., Bussmann, 1011 M. \& Weber, C. 2009: Anatomy of a subaqueous ice-contact fan and delta complex, 1012 Middle Pleistocene, north-west Germany. Sedimentology 56, 1041-1076.

1013 Wood, S. V. 1868: On the Pebble Beds of Middlesex, Essex and Herts. Quaterly Journal of 1014 the Geological Society of London 24, 464-472.

1015

1016 


\section{FIGURES:}

Fig. 1. A. The North Sea Lake, the Anglian (Elsterian) glaciation extent and drainage pattern in north-western Europe. Light grey = ice-sheet, dark-grey = water, white = land masses. Black arrows indicate the direction of drainage. Dashed-and-dotted line indicate position of the Anglian ice-sheet margin. Dashed line links the area shown in Fig. 1B with the outline on the map in Fig. 1C. Question marks indicate areas where the evidence for the presence and extent of the North Sea Lake is missing. Based on Cohen et al. (2005), Ehlers et al. (2011), Laban \& van der Meer (2011) and Roskosch et al. (2011).

B. Pre-Anglian course of the River Thames and Medway. Based on Bridgland (1995).

C. Diverted River Thames and the Anglian ice-sheet margin (dashed line). Based on Bridgland (1995).

D. The geological map of East Anglia, England. The black box indicates the Birch-Stanway research area. BQ = Birch Quarry; SQ = Stanway Quarry. Contour lines (grey, every $30 \mathrm{~m}$ ) and shoreline after Ordnance Survey of Great Britain.

E. A detailed geological map of the Birch-Stanway area. Stars mark the location of Birch and Stanway quarries.

Fig. 2. Photopanels depicting facies associations and large scale geometry of the deposits at Stanway Quarry (SQ). Scale bars are $1 \mathrm{~m}$ long.

A. Panorama of the northernmost face at SQ. The black box indicates the location of photopanel B. Inset: location of photopanels within the quarry.

B. Two overlying units of $\mathrm{G} 2$ divided by erosional/non-deposition boundary (thick, black line) in the northern part of SQ. Massive to horizontally diffusely-stratified gravel interbedded with massive to planar parallel-bedded sand. 
C. A view of the two overlying units of G2. The black box indicates the location of photopanels D, E.

D. A detailed view of the lower gravelly unit of G2. Massive to horizontally diffusely-stratified gravel interbedded with massive to planar parallel-bedded sand.

E. Ice-wedge cast within the lower gravelly unit of G2 composed of horizontally diffuselystratified gravel interbedded with massive sand.

F. Gradual vertical transition between massive to horizontally diffusely-stratified gravel interbedded with massive to planar cross-bedded sand of G2 and tabular beds of massive to planar parallel-bedded with lenses of granule gravel of S1.

G. The lowermost unit of G1 - crudely horizontally-stratified gravel with solitary planar crossstratification, with visible erosional surface.

H. A sharp but non-erosive horizontal boundary between the lower unit of gravel G2 arranged in tabular cross-beds and unit S1 of tabular beds of planar parallel-bedded to massive sand.

I. Details of transition between S1 tabular and lenticular beds of massive to planar parallel- and planar cross-bedded sand and overlying recurring cycles of fining upward sand, silt and clay arranged in small scale planar-laminations and climbing ripple cross-laminations of unit F1 in the southern part of SQ.

J. Large-scale geometry of tabular beds of planar parallel-bedded to massive sand of S1, recurring cycles of fining upwards planar and climbing ripple cross-laminated sand, silt and clay of F1 and tabular and lenticular beds of massive gravel G2 in the southern part of SQ.

K. L. Details of transition between F1 and overlying G2 in the southern part of SQ. Note the erosional lower boundary of the gravel unit G2. 
M. The horizontal boundary between unit G3 of well-defined planar cross-bedded gravel and of tabular and lenticular beds of massive to planar parallel-, trough and cross-bedded sand of S1 with some chutes-and-pools deposits.

N. Photopanel depicting unit S1 in the southern part of SQ, comprising tabular and lenticular beds of planar-parallel and planar-cross and trough-cross bedded sand with some chutes-andpools deposits. Position of detailed images O, P, R.

O. Tabular planar-cross and trough-cross bedded sand deposits.

$\mathrm{P}$ and R. Tabular planar-parallel and planar-cross and trough-cross bedded sand deposits with chute-and-pools deposits.

Fig. 3. Composite log depicting general succession of facies associations in Stanway Quarry (SQ). For location of SQ see Fig. 1.

Fig. 4. Uninterpreted (upper) and interpreted (lower) GPR transects and boreholes from Stanway Quarry. A. Location map of transects. B. Transect 1, borehole bhS1. Note the multiple lobeshaped features $\left(\operatorname{dip} \sim 10^{\circ}\right.$ ) defined as convex-up architectural elements and erosional troughs, identified as concave-up features across flow direction C. Transect 2, borehole bhS2. Note the low-angle clinoforms in the direction of flow.

Fig. 5. Geological cross-sections based on borehole data from the vicinity of the Birch and Stanway quarry. A. Stanway Quarry borehole (1-9 and 10-20) locations. B. Birch Quarry borehole (1-7 and 8-14) locations. C. Stanway Quarry geological cross-section. D. Birch Quarry geological cross-section. 
Fig. 6. Photopanels depicting large scale geometry of the deposits at Birch Quarry (BQ). Scale bars are $1 \mathrm{~m}$ long.
A. Panorama of the north-western part of BQ. Black boxes indicate the location of photopanels Inset: location of photopanels.
B. Lowermost gravelly unit G2.
C. Vertical transition between G2 and S1.
D. Sandy unit S1.
E. Vertical transition between units S1 and G2.
F. The erosional/non-depositional surface at 30-31 m OD with two ice-wedge casts and overlying unit G2.
G. Upper unit G2.
H. Undulating erosional boundary between uppermost unit G2 and diamicton of D1.
I. J. Details of deformation structures within sandy unit S1 below diamicton D1.
K. L. Boundary between sandy unit S1 and overlying unit of diamicton D1 in the southernmost part of BQ.

Fig. 7. Composite log depicting general succession of facies associations in Birch Quarry (BQ).

Fig. 8. Schematic drawing of the lithofacies associations described from the Birch-Stanway area. Black boxes indicate locations depicted in details by photopanels. A. Stanway Quarry deposits. Letters A-P indicate the photopanels within Fig. 2, where detailed images of the selected exposures from Stanway Quarry are presented. B. Location of the Stanway Quarry cross-section. C. Location of the Birch Quarry cross-section. D. Birch Quarry deposits. Letters A-L indicate the 
photopanels within Fig. 6, where detailed images of the selected exposures from Birch Quarry are presented.

Fig. 9. A schematic drawing of Birch-Stanway complex fan. A. Black arrows indicate the direction of pre-Anglian Thames river flow. B. Black arrows indicate the generalized palaeocurrent direction of Anglian meltwater flow in the area of the subaqueous fan described from the Birch-Stanway area. The black dashed line marks the Anglian ice-sheet margin, and the transparent white marks, the area of the Birch-Stanway complex fan.

\section{Tables:}

Table 1: Lithological composition of the Kesgrave Formation and Lowestoft Formation samples - overview of published research.

Table 2: Overview of the provenance of lithological components of sand and gravel from the Birch-Stanway area.

Table 3: Facies identification codes and descriptions as used in the current research.

Table 4: Facies associations and their characteristics as used in the current research.

Table 5: Clast lithological analysis results: B1-B12 - Birch Quarry samples, S1-S14 - Stanway Quarry samples. 


\section{Supporting Information:}

Fig. S1. A. Birch Quarry plan. Note: sections - black dots, cross-sections BQ1-BQ2 and BQ3BQ4 (on-line support material 2 and 3) - grey dashed lines, cross-section M-N (Fig. 10) - grey line.

Fig. S2. Geological cross-section BQ1-BQ2 based on vertical profile logs from Birch Quarry. For location see Fig. S1.

Fig. S3. Geological cross-section BQ3-BQ4 based on vertical profile logs from Birch Quarry. For location see Fig. S1.

Fig. S4. Geological cross-section SQ1-SQ2 based on vertical profile logs from Stanway Quarry. For location Fig. S1.

Fig. S5. Geological cross-section SQ3-SQ4 based on vertical profile logs from Stanway Quarry. For location see Fig. S1.

Fig. S6. Schematic drawing of the facies associations described from the Birch-Stanway area A. Stanway Quarry deposits. Black boxes indicate locations depicted in details by section logs. B. Birch Quarry deposits. Black boxes indicate locations depicted in details by section logs. 


\begin{tabular}{|c|c|c|c|c|}
\hline \multirow{2}{*}{ Reference } & $\begin{array}{c}\text { Stratigraphic } \\
\text { interpretation/ } \\
\text { formation or member }\end{array}$ & Site/location & \% of flint & $\begin{array}{c}\% \text { of } \\
\text { quartz and } \\
\text { quartzite }\end{array}$ \\
\hline $\begin{array}{c}\text { Hey (1980) and } \\
\text { Whiteman (1992) }\end{array}$ & Glacial gravel & Tiptree & 83 & 15.1 \\
\cline { 2 - 5 } Rose et al. (1999) & $\begin{array}{c}\text { Glacial gravel } \\
\text { Karious members of the } \\
\text { Kesgrave Formation in } \\
\text { Essffolk and south } \\
\text { Norfolk }\end{array}$ & Great Dunmow & 70.6 & 28.4 \\
\hline $\begin{array}{c}\text { Green \& McGregor } \\
(1999)\end{array}$ & $\begin{array}{c}\text { Gravel of the Kesgrave } \\
\text { Formation type in northern } \\
\text { Suffolk and Norfolk }\end{array}$ & not known & $64.9-83.3$ & $12-29.8$ \\
\cline { 2 - 5 } & Kesgrave Formation type & not known & $43.1-74.8$ & $8-15.6$ \\
\hline Green et al. (1982) & Glacial gravel & not known & 79.4 & -32 \\
\hline
\end{tabular}




\begin{tabular}{|c|c|c|}
\hline Lithology & Provenance & Reference \\
\hline \multicolumn{3}{|c|}{ Associated with glacial origin of deposits } \\
\hline \multirow{3}{*}{$\begin{array}{l}\text { Flint } \\
\text { (angular and } \\
\text { nodular) }\end{array}$} & $\begin{array}{l}\text { Directly from chalk underlying the London Clay bedrock; } \\
\text { Reworked from the local Tertiary pebble beds: }\end{array}$ & Green \& McGregor (1978) \\
\hline & Upper and Middle Chalk & Bridgland (1986) \\
\hline & $\begin{array}{l}\text { London Basin Tertiary; } \\
\text { Chalk; }\end{array}$ & Hey $(1965,1967,1976)$ \\
\hline \multirow[b]{2}{*}{ Rounded flint } & London Basin Tertiary beds & Hey $(1967,1965)$ \\
\hline & Kesgrave Formation & $\begin{array}{l}\text { Rose et al. (1977) } \\
\text { Rose \& Allen (1977) }\end{array}$ \\
\hline \multirow[b]{2}{*}{ Rhaxella Chert } & Northern British provenance & Green et al. $(1980$ \\
\hline & $\begin{array}{l}\text { Corralian Beds of the Upper Jurassic in east Yorkshire; } \\
\text { North-east of Oxford; } \\
\text { Red Crag near Ipswich; }\end{array}$ & Hey (1976) \\
\hline \multicolumn{3}{|c|}{ associated with non-glacial, fluvial (proto-Thames) origin of deposits } \\
\hline \multirow{4}{*}{ Quartz } & $\begin{array}{l}\text { Bunter Pebbles Beds of English Midlands; } \\
\text { Palaeogene formations within the present catchment of the } \\
\text { Thames; }\end{array}$ & Green \& McGregor (1978) \\
\hline & $\begin{array}{l}\text { Mesozoic rocks of western and northern Britain; } \\
\text { The Devonian conglomerates of the Welsh borderlands; } \\
\text { Various Permo-Triassic conglomerates and breccia of the West } \\
\text { Midlands; } \\
\text { Mesozoic pebble-beds of the south Midlands }\end{array}$ & Bridgland (1986) \\
\hline & $\begin{array}{l}\text { Reading Beds of East Anglia; } \\
\text { Bunter and Lower Carboniferous of the southern Penines; }\end{array}$ & Hey $(1965,1967,1976)$ \\
\hline & Belgium (historical view) & Prestwich (1890) \\
\hline \multirow[t]{2}{*}{ Quartzite } & $\begin{array}{l}\text { Bunter Pebble Beds of Midlands; } \\
\text { Permo-Triassic beds of Midlands; } \\
\text { Devonian conglomerates of the Welsh borderlands; } \\
\text { Precambrian and Paleozoic beds of the Midlands-Welsh } \\
\text { borderlands; }\end{array}$ & Bridgland (1986) \\
\hline & Bunter Pebble Beds of English Midlands & $\begin{array}{l}\text { Hey }(1965,1967,1976) \\
\text { Hey \& Brenchley }(1977)\end{array}$ \\
\hline \multirow{3}{*}{$\begin{array}{l}\text { Sandstone and } \\
\text { siltstone }\end{array}$} & Bunter Pebbles Beds of English Midlands; & Green \& McGregor (1978) \\
\hline & The Dengie Peninsula north of the Thames & $\begin{array}{l}\text { Bridgland (1986) } \\
\text { Bridgland (1988) }\end{array}$ \\
\hline & $\begin{array}{l}\text { Corralian Beds of the Upper Jurassic in east Yorkshire; } \\
\text { North-east of Oxford; } \\
\text { Red Crag near Ipswich; }\end{array}$ & Hey (1976) \\
\hline Pinhole Chert & $\begin{array}{l}\text { The Lower Greensand of the northern margin of the Weald; } \\
\text { Southern Penines; }\end{array}$ & Неy $(1967,1976)$ \\
\hline \multirow[b]{2}{*}{ Greensand Chert } & South-Eastern Essex & $\begin{array}{l}\text { Gregory (1915), } \\
\text { Green \& McGregor (1978) } \\
\text { Green et al. (1980) }\end{array}$ \\
\hline & $\begin{array}{l}\text { Hythe Beds in Kent, west of Sevenoaks and western Weadland; } \\
\text { Folkestone Beds and Bargeat of Sandgate Beds of Surrey; } \\
\text { Lower Greensand of the Farington district of Oxfordshire; } \\
\text { Upper Bagshot and Pebble Beds of northern Surrey; }\end{array}$ & $\begin{array}{l}\text { Bridgland (1986) } \\
\text { Bridgland (1988) }\end{array}$ \\
\hline \multirow[t]{2}{*}{$\begin{array}{l}\text { Volcanic } \\
\text { rocks }\end{array}$} & Ordovician beds of North Wales & $\begin{array}{l}\text { Hey \& Brenchley }(1977,1978) \\
\text { Green \& McGregor }(1978) \\
\text { McGregory \& Green (1978) } \\
\text { Green et al.(1980) }\end{array}$ \\
\hline & The Cretacerous beds of the southern and south-eastern Midlands & $\begin{array}{l}\text { Salter }(1905), \\
\text { Gregory }(1922)\end{array}$ \\
\hline \multirow[t]{2}{*}{ Igneous rocks } & $\begin{array}{l}\text { Wales; } \\
\text { Welsh Borderlands; } \\
\text { West Midlands; }\end{array}$ & Bridgland (1986) \\
\hline & Bunter Pebble Beds of Midlands & Hey (1976) \\
\hline
\end{tabular}




\begin{tabular}{|c|c|}
\hline $\begin{array}{l}\text { Facies } \\
\text { code }\end{array}$ & Description \\
\hline $\mathrm{Gmm}$ & Massive, matrix-supported, poorly sorted, pebble to cobble gravel; matrix is fine to coarse sand \\
\hline Gmp & $\begin{array}{l}\text { Planar cross-stratified, poorly sorted, granule to pebble, matrix-supported gravel; matrix is fine to } \\
\text { coarse sand; occasionally normally graded }\end{array}$ \\
\hline Gmt & $\begin{array}{l}\text { Trough cross-stratified, poorly sorted, granule to pebble, matrix-supported gravel; matrix is fine to } \\
\text { coarse sand; multiple scour-fills, erosional and recurrent surfaces }\end{array}$ \\
\hline $\mathrm{Gmh}$ & $\begin{array}{l}\text { Diffusely horizontally stratified, poorly sorted, pebble to cobble, matrix-supported gravel; matrix } \\
\text { is fine to coarse sand; horizontal stratifications with conformable bases }\end{array}$ \\
\hline Gcm & Massive, poorly sorted, pebble to cobble, clast-supported gravel \\
\hline Gcp & $\begin{array}{l}\text { Solitary or planar cross-stratified, poorly sorted, pebble to cobble, clast-supported (openwork) } \\
\text { gravel }\end{array}$ \\
\hline $\mathrm{Sm}$ & Massive, poorly sorted, fine to coarse sand, may be with isolated pebbles \\
\hline Sh & $\begin{array}{l}\text { Horizontally stratified (occasionally diffusely horizontally stratified), poorly sorted, fine to coarse } \\
\text { sand, with occasional pebble trains, often occurs together with facies Sm }\end{array}$ \\
\hline Sp & $\begin{array}{l}\text { Solitary or planar cross-bedded, poorly sorted, fine to coarse sand, with occasional pebble trains; } \\
\text { ultiple erosional surfaces and occasional scour-fills and chutes-and-pools with planar to sigmoidal } \\
\text { and concave-up, downflow-divergent cross-beds - backsets (bed dip less than } 10 \text { degrees) and rare boundary } \\
\text { conformable laminae }\end{array}$ \\
\hline St & $\begin{array}{l}\text { Trough cross-bedded, poorly sorted, fine to coarse sand with occasional pebble trains; multiple } \\
\text { erosional surfaces and scour-fills }\end{array}$ \\
\hline $\mathrm{Sd}$ & $\begin{array}{l}\text { Poorly sorted, fine to coarse sand with deformed bedding, mainly deformed horizontal } \\
\text { stratification }\end{array}$ \\
\hline Fm & Massive silt and clay, very stiff \\
\hline Fl & Finely laminated silt and clay, in places diffusely, occasionally graded \\
\hline Fsl & Small scale planar cross-stratified sand silt and clay \\
\hline $\mathrm{Dm}$ & Massive diamict which consists of sandy silty clay with stones \\
\hline
\end{tabular}




\begin{tabular}{|c|c|c|c|c|}
\hline $\begin{array}{c}\text { Facies } \\
\text { association }\end{array}$ & $\begin{array}{c}\text { Component } \\
\text { facies }\end{array}$ & Description & Geometry and dimensions & Interpretation \\
\hline $\begin{array}{l}\text { G1 } \\
\text { Crudely } \\
\text { horizontally and } \\
\text { solitary planar } \\
\text { cross-bedded } \\
\text { clast and matrix } \\
\text { supported gravel }\end{array}$ & $\begin{array}{l}\text { Gmm } \\
\text { Gmp } \\
\text { Gcm } \\
\text { Gcp } \\
\text { Shp }\end{array}$ & $\begin{array}{l}\text { Throughout the whole thickness of } \\
\text { the facies, clay inatraclasts (rip-up } \\
\text { clasts) are abundant; sedimentary } \\
\text { structures: crudely horizontally } \\
\text { stratified, planar to solitary cross- } \\
\text { stratified matrix-supported, clast } \\
\text { supported and open-work gravel; } \\
\text { multiple scour-fills, erosional and } \\
\text { recurrent surfaces; discontinuous, } \\
\text { tabular beds of horizontally and } \\
\text { diffusely horizontally stratified } \\
\text { sand; imbricated and a-transverse } \\
\text { oriented pebbles are present bed } \\
\text { contact: erosive }\end{array}$ & $\begin{array}{l}\text { Forms long, tabular units a few } \\
\text { metres thick and few tens of } \\
\text { metres long which consist of } \\
0.2-1 \mathrm{~m} \text { thick lenticular beds } \\
\text { with frequent scour fills filled } \\
\text { with massive or cross-stratified } \\
\text { gravel; scours are } 0.1-0.4 \mathrm{~m} \\
\text { deep and laterally extend for } \\
\text { few to } 20 \mathrm{~m} \text {; sandy beds are } \\
0.2-0.3 \mathrm{~m} \text { thick }\end{array}$ & $\begin{array}{l}\text { Indicates transport of fluvial bedload on a braidplain as bars } \\
\text { (Boothroyd \& Ashley, 1975, Plink-Bjorklund \& Ronnert, 1999) } \\
\text { or downflow migration of 2D (tabular cross-stratification) and } \\
\text { 3D (trough cross-stratification) dunes (Harms et al. 1975, Allen } \\
\text { 1982, Russel \& Arnott 2003) (subcritical flow conditions); the } \\
\text { presence of solitary cross-stratification, together with imbricated } \\
\text { and a-transverse-oriented pebbles, is a reliable indication of } \\
\text { palaeocurrent direction (Evans \& Benn 2004); abundant presence } \\
\text { of intraclasts is evidence for erosion of the underlying London } \\
\text { Clay }\end{array}$ \\
\hline \begin{tabular}{l}
\multicolumn{1}{c}{ G2 } \\
Horizontally \\
diffusely \\
stratified and \\
massive \\
gravel and sand
\end{tabular} & $\begin{array}{c}\text { Gmh } \\
\text { Gmm } \\
\text { Sh } \\
\text { Sm }\end{array}$ & $\begin{array}{l}\text { Sedimentary structures: } \\
\text { horizontally or diffusely-stratified } \\
\text { gravel and sand; occasionally planar } \\
\text { cross-stratified, planar parallel } \\
\text { stratified (with granules and } \\
\text { pebbles as horizontal trains within } \\
\text { sandy beds) or massive; bed } \\
\text { contact: erosive or sharp but non- } \\
\text { erosive }\end{array}$ & $\begin{array}{l}\text { Gravel a few tens of centimetres } \\
\text { to few metres thick; sand } 0.1-1 \\
\mathrm{~m} \text { thick; both extend laterally } \\
\text { for a few tens of metres; sand } \\
\text { beds thicken where gravel beds } \\
\text { thin }\end{array}$ & $\begin{array}{l}\text { Traction deposition from high-density turbidity currents (Church } \\
\text { \& Gilbert 1975, Russel \& Arnott 2003); sand deposited from } \\
\text { non-turbulent flow of sandy debris in conditions of high sediment } \\
\text { supply from suspension following deceleration of high-velocity } \\
\text { sediment-laden flow ( Tucker 1982, Maizels 1993, Sihne et al. } \\
\text { 1997, Shanmugam 2000, Bennet et al. 2002, Winsemann et al. } \\
\text { 2009); thick and laterally extensive beds suggests that these } \\
\text { depositional conditions sustained for longer periods of time } \\
\text { (Kneller \& Branley, 1995; Winsemann et al. 2007, 2009); } \\
\text { current research regards diffusely-stratified bedforms as being } \\
\text { antidune deposits, associated with supercritical flow conditions } \\
\text { (Lang \& Winsemann 2013) }\end{array}$ \\
\hline
\end{tabular}




\begin{tabular}{|c|c|c|c|c|}
\hline $\begin{array}{l}\text { G3 } \\
\text { large scale, planar } \\
\text { cross-stratified } \\
\text { gravel }\end{array}$ & Gmp & $\begin{array}{l}\text { Sedimentary structures: well } \\
\text { defined planar-cross stratification, } \\
\text { concave-up to convex-up; } \\
\text { occasionally normal grading occurs; } \\
\text { individual beds dip with an angle } \\
\text { between } 15 \text { and } 22 \text { degrees; wide } \\
\text { range of dip directions, from the } \\
\text { south-east to west; basal contact: } \\
\text { tangential to angular; bed contact: } \\
\text { erosive }\end{array}$ & $\begin{array}{l}\text { Individual bed is } 0.5 \mathrm{~m} \text { to few } \\
\text { metres thick and extend } \\
\text { laterally for more than } 50 \mathrm{~m} \text {; } \\
\text { within discrete depositional } \\
\text { unit, usually occurs only one } \\
\text { bed of this characteristics }\end{array}$ & $\begin{array}{l}\text { Cross-stratification represent migrating } 2 \text { or } 3 \mathrm{D} \text { dunes associated } \\
\text { with high turbulent flows and constant discharge from longer } \\
\text { periods of time; the dimension and angles of the bed dip indicate } \\
\text { the formation of shallow-water delta mouthbars or large scou- } \\
\text { fills (Winsemann et al. 2009) }\end{array}$ \\
\hline $\begin{array}{l}\text { S1 } \\
\text { planar } \\
\text { cross-bedded and } \\
\text { trough cross- } \\
\text { bedded sand with } \\
\text { pebbles }\end{array}$ & $\begin{array}{c}\mathrm{Sp} \\
\mathrm{St} \\
\mathrm{Sm} \\
\mathrm{Gmp}\end{array}$ & $\begin{array}{l}\text { Gmp occurs very occasionally as } \\
\text { solitary sets of cross-beds; } \\
\text { sedimentary structures: lenticular } \\
\text { and planar beds of cross-stratified } \\
\text { sand; lenticular beds of trough- } \\
\text { stratified sand; multiple erosional } \\
\text { and reactivation surfaces and scour } \\
\text { fills; bed contact: sharp, but non- } \\
\text { erosive or erosive }\end{array}$ & $\begin{array}{l}\text { Beds of planar cross-stratified } \\
\text { sand are } 0.2-0.5 \mathrm{~m} \text { thick and } \\
\text { laterally extend up to several m; } \\
\text { troughs of cross-bedded sand } \\
\text { are } 0.2 \text { to } 0.5 \mathrm{~m} \text { thick and } 2-10 \\
\mathrm{~m} \text { wide, planar to sigmoidal and } \\
\text { concave-up, downflow- } \\
\text { divergent cross-beds (backsets, } \\
\text { dipping to the north and north- } \\
\text { west with an angle of less than } \\
10^{\circ} \text { ) and rare boundary- } \\
\text { conformable laminae; erosional } \\
\text { scours are filled with sigmoidal } \\
\text { cross-beds; both chutes-and- } \\
\text { pools and erosional scours are } \\
10 \text { to } 50 \text { cm deep and a few m } \\
\text { in lateral extent }\end{array}$ & $\begin{array}{l}\text { Planar and trough cross-bedded sand reflects downflow migration } \\
\text { of 2D and 3D dunes, respectively; reactivation surfaces indicate } \\
\text { flow and discharge variability (Collinson 1970; Marren 2004), } \\
\text { thick successions indicate that these subcritical depositional } \\
\text { conditions persisted for longer periods of time (Mulder \& } \\
\text { Aleksander 2001, Kneller 2004); chutes-and-pools are evidence } \\
\text { of supercritical flow conditions (Lang \& Winsemann 2013) }\end{array}$ \\
\hline
\end{tabular}




\begin{tabular}{|c|c|c|c|c|}
\hline $\begin{array}{l}\text { F1 } \\
\text { normally graded } \\
\text { sand, } \\
\text { silt and clay }\end{array}$ & $\begin{array}{l}\text { Fsl } \\
\text { Fl } \\
\text { Fm }\end{array}$ & $\begin{array}{l}\text { Sedimentary structures: recurring } \\
\text { successions of massive or normally- } \\
\text { graded sand that fines upwards into } \\
\text { massive, planar-parallel or small- } \\
\text { scale climbing ripple and climbing } \\
\text { planar cross-laminated silt and clay; } \\
\text { bed contact: sharp }\end{array}$ & $\begin{array}{l}\text { Tabular beds of sand are }<10 \\
\mathrm{~cm} \text { thick and grade into silt and } \\
\text { clay beds which are } 2-20 \mathrm{~cm} \\
\text { thick; both extend laterally for } \\
\text { few tens of metres; when stiff } \\
\text { massive clay and silt-tabular } \\
\text { beds are } 0.05 \text { to few tens of cm } \\
\text { thick, they laterally extend for a } \\
\text { few metres to a few tens of m }\end{array}$ & $\begin{array}{l}\text { Lower flow regime; fining upward successions of sand, silt, clay } \\
\text { indicate the waning stage of the flow of surge-like turbidity } \\
\text { currents (Bouma, 1962, Plink-Bjorklund \& Ronnert 1999, } \\
\text { Mulder \& Alexander 2001) or conditions of expanding flow of } \\
\text { density underflows (Walker 1992); low-energy current ripples } \\
\text { and climbing planar cross-lamination indicates the migration of } \\
\text { low-energy current ripples and combined deposition form } \\
\text { traction and suspension, occurring as the flow decelerates, losing } \\
\text { transport capacity (Ashley et al. 1982, Jopling \& Walker 1968); } \\
\text { massive silty-clay is deposited from waning low density } \\
\text { turbidity currents (Russel \& Arnott, 2003) or suspension } \\
\text { sedimentation within glacilacustrine basin (Collinson \& } \\
\text { Thompson 1989, Gilbert 1997, Reineck \& Singh 1980) massive } \\
\text { clay deposited in conditions of no meltwater discharge, winter } \\
\text { (Russel \& Arnott 2003) }\end{array}$ \\
\hline D1 & $\mathrm{Dm}$ & $\begin{array}{l}\text { No sedimentary structures - } \\
\text { massive, tructurless; bed contact: } \\
\text { undulating, erosive }\end{array}$ & $\begin{array}{l}\text { Tabular units with undulating } \\
\text { lower contact are few metres } \\
\text { thick and laterally extend for a } \\
\text { few hundred } m\end{array}$ & $\begin{array}{l}\text { The presence of weathered chalk granules indicates that the } \\
\text { diamict is genetically associated with the ice-sheet (Allen 1991); } \\
\text { deposited as a solifluction or directly from the ice-sheet as till }\end{array}$ \\
\hline
\end{tabular}




\begin{tabular}{|c|c|c|c|c|c|c|c|c|c|}
\hline $\begin{array}{l}\text { sample } \\
\text { ID }\end{array}$ & $\begin{array}{c}\% \\
\text { angular } \\
\text { flint }\end{array}$ & $\begin{array}{c}\% \\
\text { rounded } \\
\text { flint }\end{array}$ & $\begin{array}{c}\% \\
\text { nodular } \\
\text { flint }\end{array}$ & $\begin{array}{c}\% \\
\text { quartz }\end{array}$ & $\begin{array}{c}\% \\
\text { quartzite }\end{array}$ & $\begin{array}{c}\% \\
\text { sandstone }\end{array}$ & $\begin{array}{c}\% \\
\text { igneous }\end{array}$ & $\begin{array}{c}\% \\
\text { pinhole } \\
\text { chert }\end{array}$ & $\begin{array}{c}\% \\
\text { greensand } \\
\text { chert }\end{array}$ \\
\hline B1 & 70.1 & 12.9 & 0.00 & 9.1 & 3.9 & 1.3 & 1.0 & 1.6 & 0.00 \\
\hline B2 & 61.6 & 15.2 & 0.16 & 14.1 & 4.6 & 1.7 & 0.5 & 2.0 & 0.00 \\
\hline B3 & 73.1 & 10.3 & 0.15 & 9.4 & 2.3 & 1.6 & 0.1 & 2.9 & 0.00 \\
\hline B4 & 43.6 & 28.9 & 0.44 & 15.8 & 9.3 & 0.6 & 0.3 & 1.0 & 0.00 \\
\hline B5 & 56.2 & 18.1 & 0.09 & 11.5 & 10.6 & 2.1 & 0.4 & 0.8 & 0.09 \\
\hline B6 & 62.5 & 15.3 & 0.00 & 13.6 & 5.5 & 1.7 & 0.2 & 0.9 & 0.24 \\
\hline B7 & 61.0 & 14.7 & 0.13 & 13.5 & 5.8 & 2.3 & 0.4 & 2.2 & 0.00 \\
\hline B8 & 62.7 & 12.3 & 0.00 & 18.1 & 4.4 & 1.1 & 0.1 & 1.2 & 0.00 \\
\hline B9 & 59.3 & 17.9 & 0.28 & 10.9 & 8.9 & 1.7 & 0.1 & 0.8 & 0.00 \\
\hline B10 & 68.4 & 14.6 & 0.64 & 10.7 & 4.0 & 0.6 & 0.2 & 0.6 & 0.16 \\
\hline B11 & 52.5 & 16.0 & 1.66 & 8.8 & 17.7 & 1.7 & 1.1 & 0.5 & 0.00 \\
\hline B12 & 73.0 & 8.5 & 0.44 & 9.0 & 4.17 & 3.5 & 0.2 & 1.1 & 0.00 \\
\hline $\mathrm{S} 1$ & 59.8 & 16.9 & 2.3 & 8.4 & 11.1 & 0.5 & 0.5 & 0.5 & 0.0 \\
\hline S2 & 49.7 & 26.3 & 0.6 & 11.8 & 10.0 & 0.2 & 0.4 & 1.1 & 0.0 \\
\hline S3 & 40.5 & 34.0 & 0.9 & 14.0 & 9.8 & 0.3 & 0.2 & 0.2 & 0.0 \\
\hline S4 & 50.8 & 27.4 & 0.0 & 11.7 & 8.1 & 0.5 & 0.7 & 0.8 & 0.0 \\
\hline S5 & 43.3 & 25.6 & 0.4 & 15.3 & 12.7 & 0.5 & 0.7 & 1.5 & 0.0 \\
\hline S6 & 51.3 & 18.9 & 0.0 & 15.7 & 10.2 & 0.6 & 1.1 & 2.2 & 0.0 \\
\hline S7 & 53.2 & 22.3 & 0.1 & 16.6 & 7.7 & 0.0 & 0.0 & 0.0 & 0.0 \\
\hline S8 & 59.1 & 13.0 & 0.0 & 10.9 & 14.6 & 1.0 & 0.1 & 1.4 & 0.0 \\
\hline S9 & 66.5 & 16.5 & 0.0 & 3.7 & 9.6 & 2.7 & 0.0 & 1.1 & 0.0 \\
\hline S10 & 73.0 & 7.1 & 0.6 & 6.3 & 5.0 & 6.1 & 0.4 & 1.5 & 0.0 \\
\hline S11 & 55.4 & 26.0 & 0.4 & 9.0 & 6.8 & 1.5 & 0.0 & 0.9 & 0.0 \\
\hline $\mathrm{S} 12$ & 39.5 & 32.5 & 0.4 & 13.3 & 10.1 & 1.5 & 0.9 & 1.7 & 0.0 \\
\hline S13 & 62.4 & 14.6 & 0.0 & 11.5 & 8.3 & 2.0 & 0.4 & 0.8 & 0.0 \\
\hline S14 & 61.0 & 14.8 & 0.4 & 15.7 & 3.8 & 4.4 & 0.0 & 0.0 & 0.0 \\
\hline
\end{tabular}




\section{Page 57 of 73}

Boreas

1

2

3

4

5

6

7

8

9

10

11

12

13

14
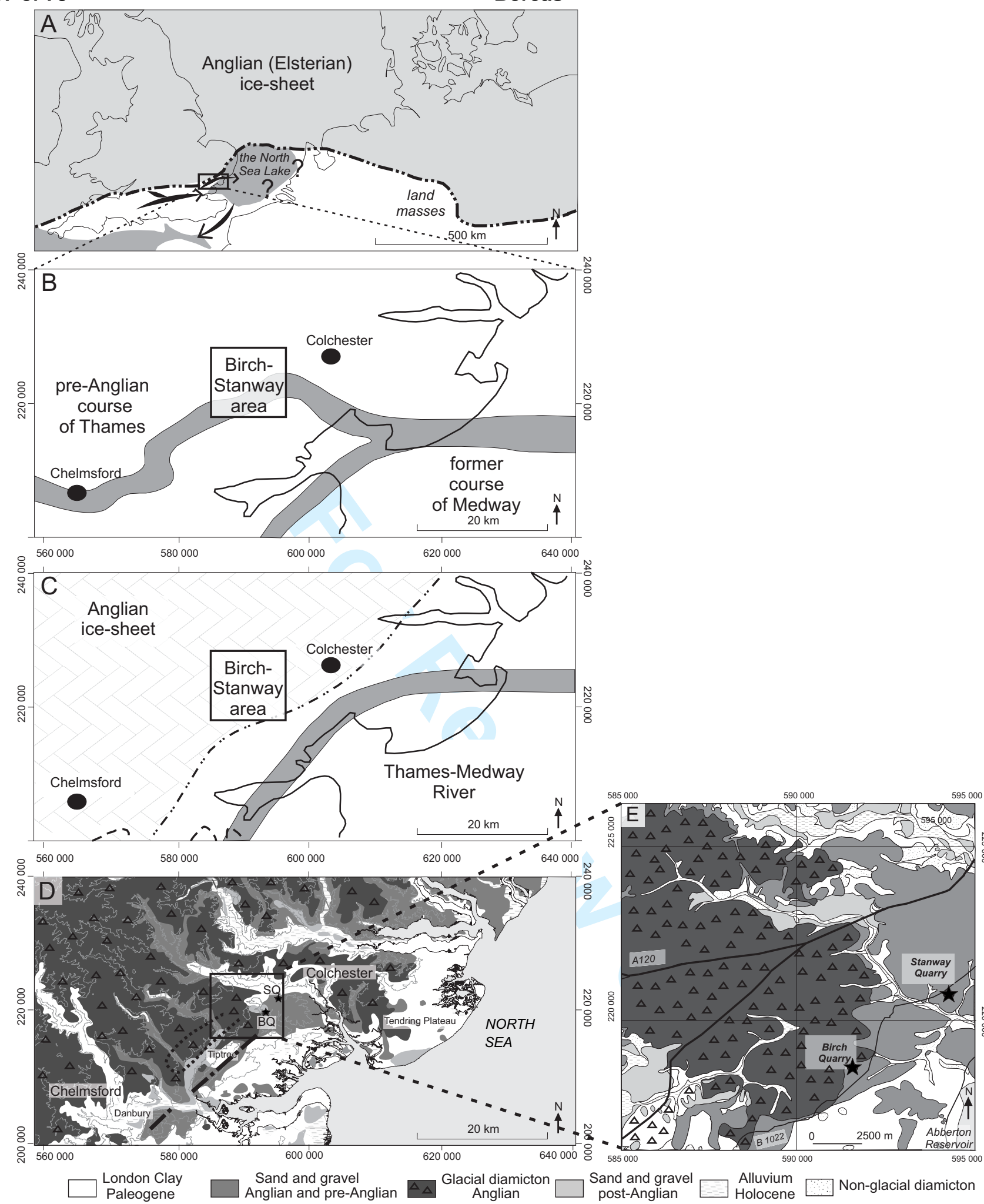

$\Delta_{\Delta} \begin{gathered}\text { Glacial diamicton } \\ \text { Anglian }\end{gathered} \square \begin{gathered}\text { Sand and grave } \\ \text { post-Anglian }\end{gathered}$

Alluvium

-. . Position of the Danbury-Tiptree ridge 

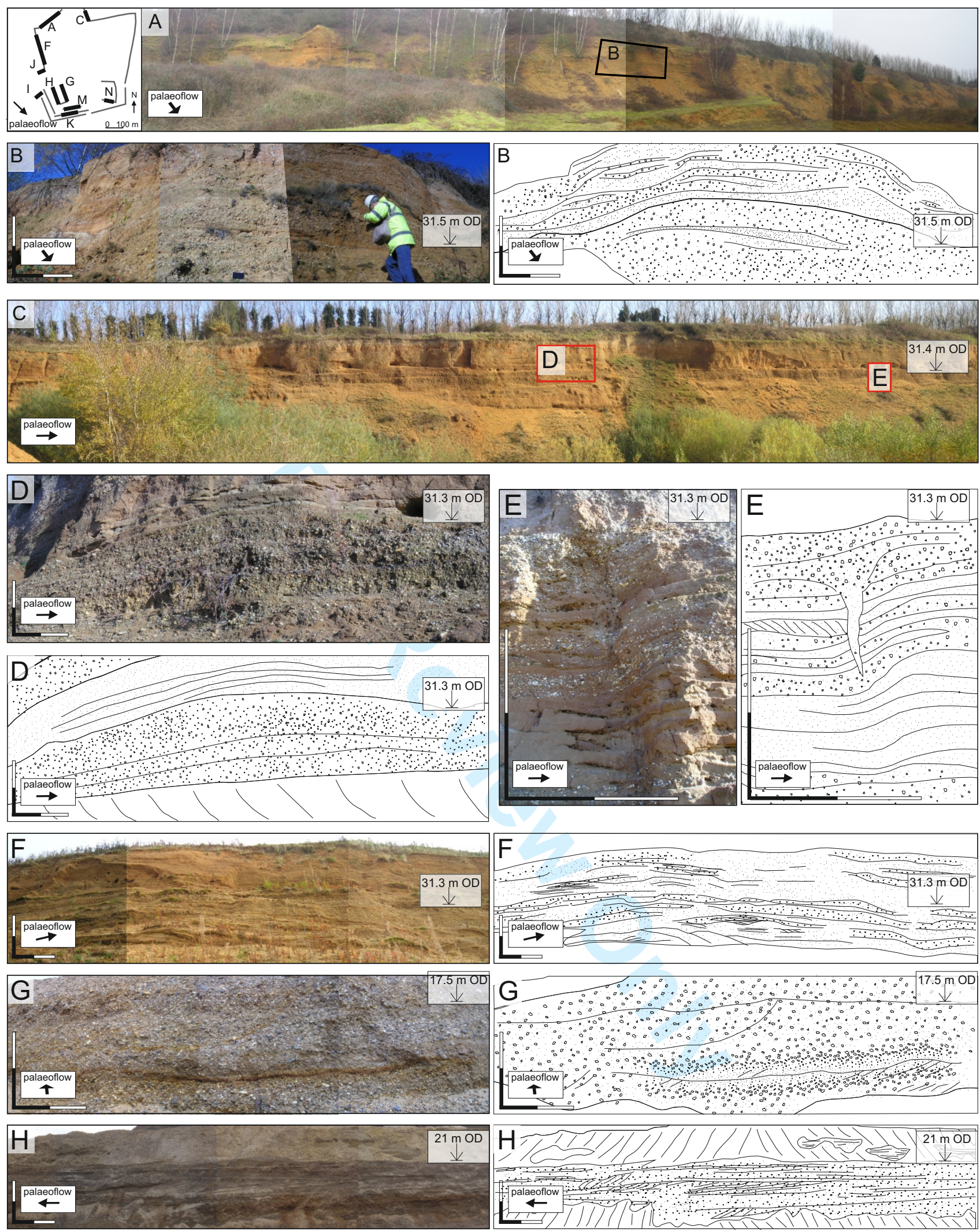

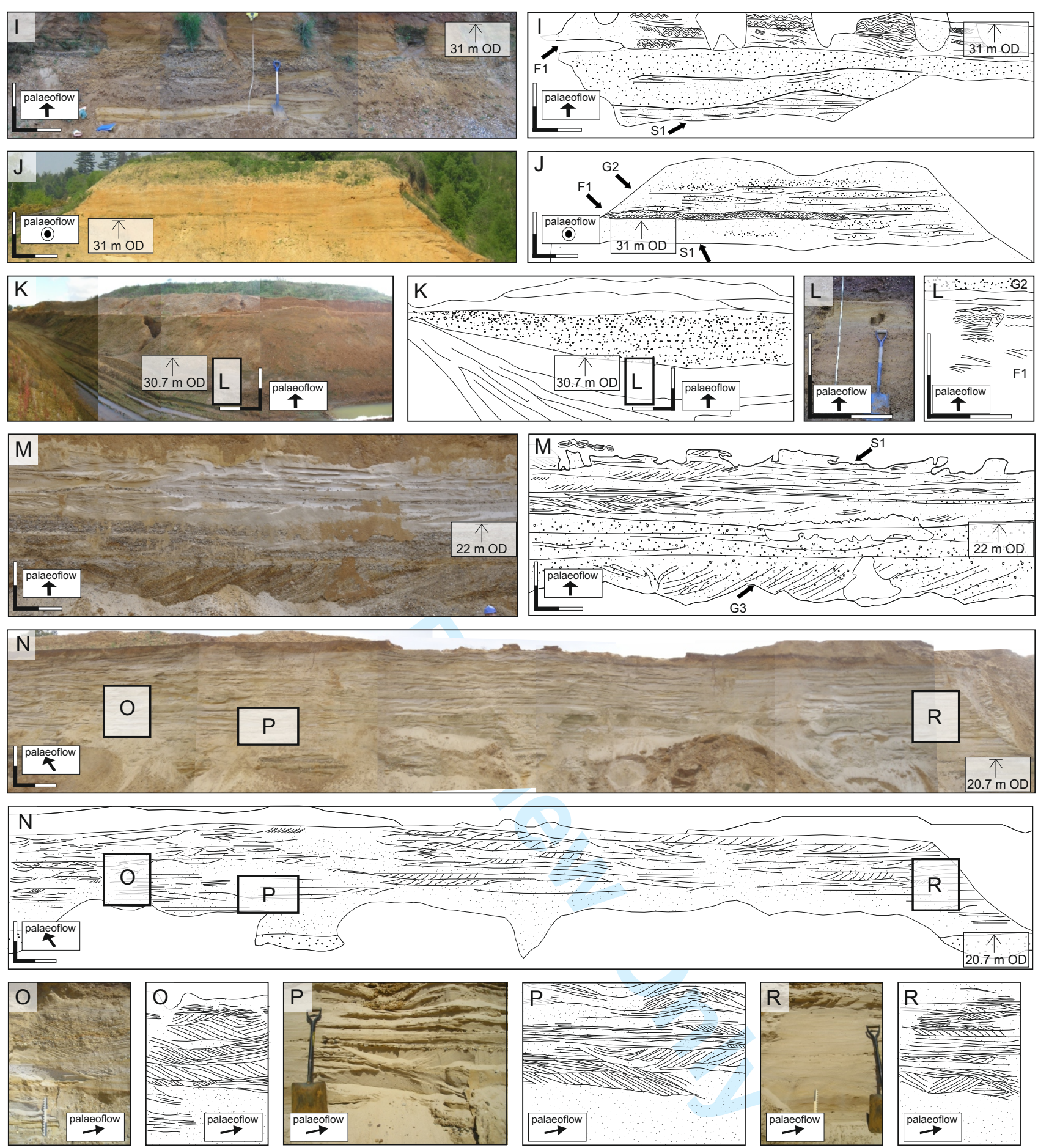

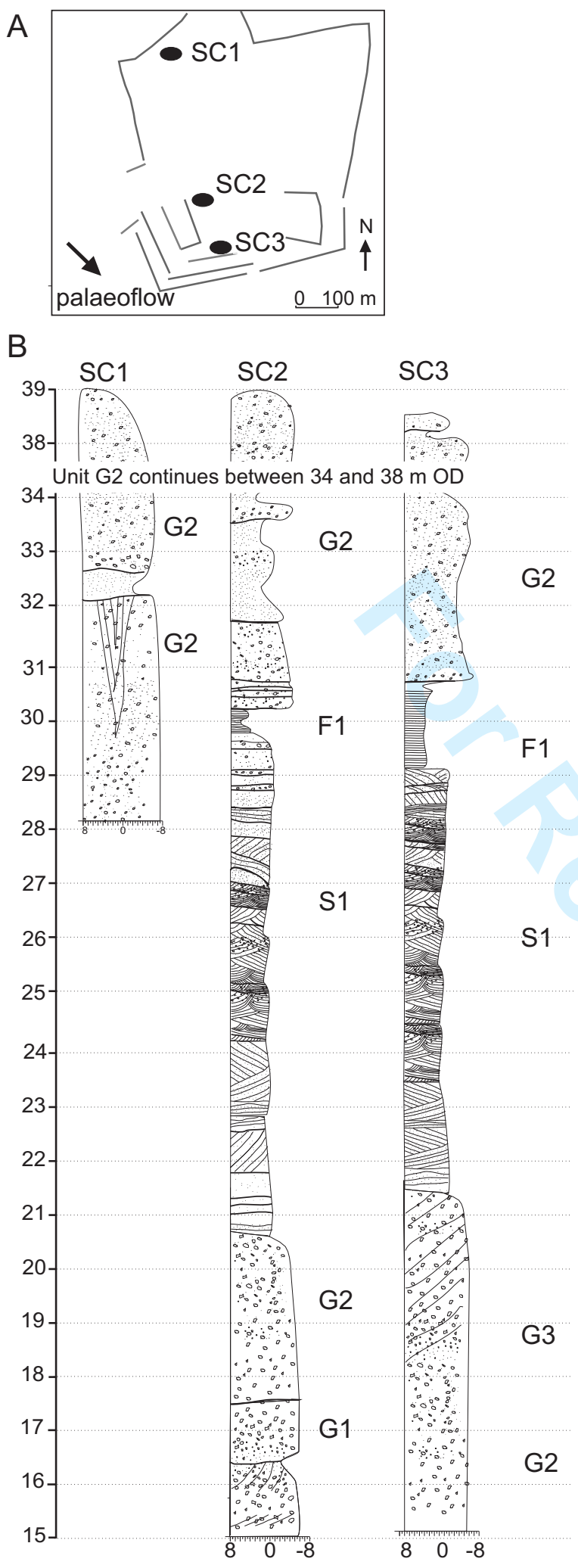


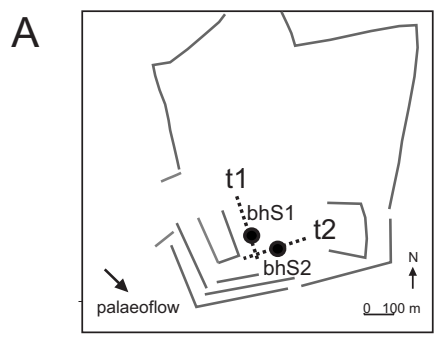

B

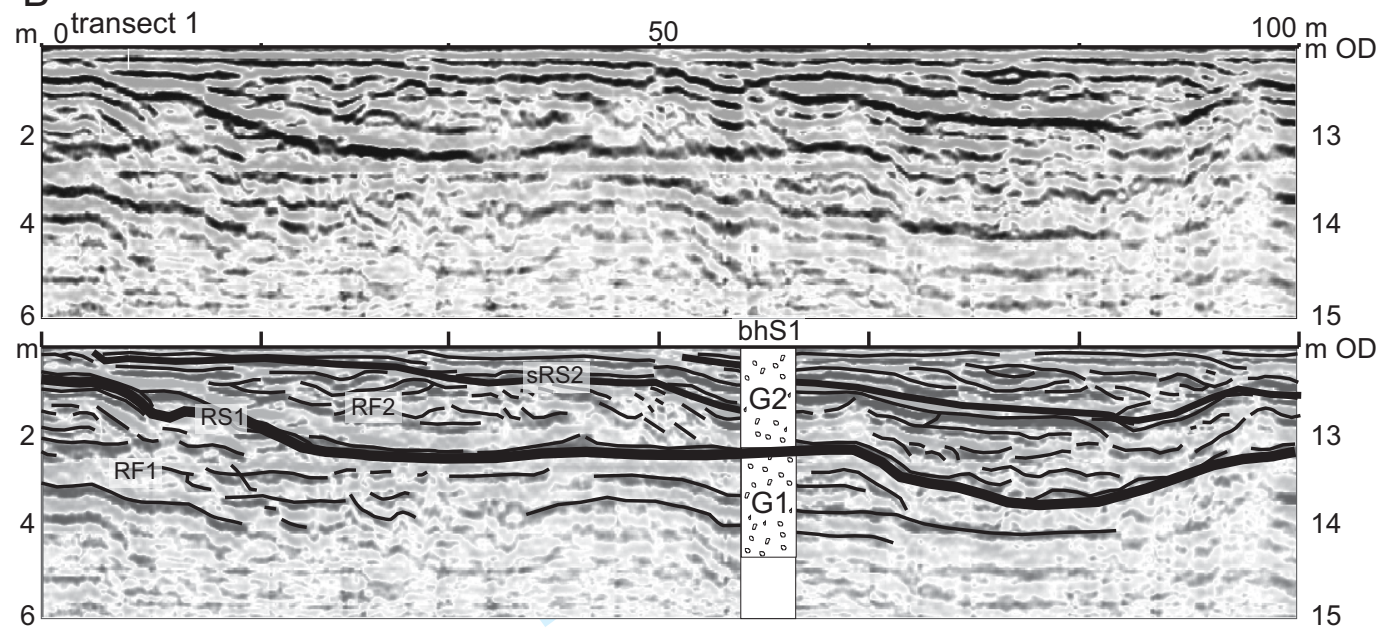

C

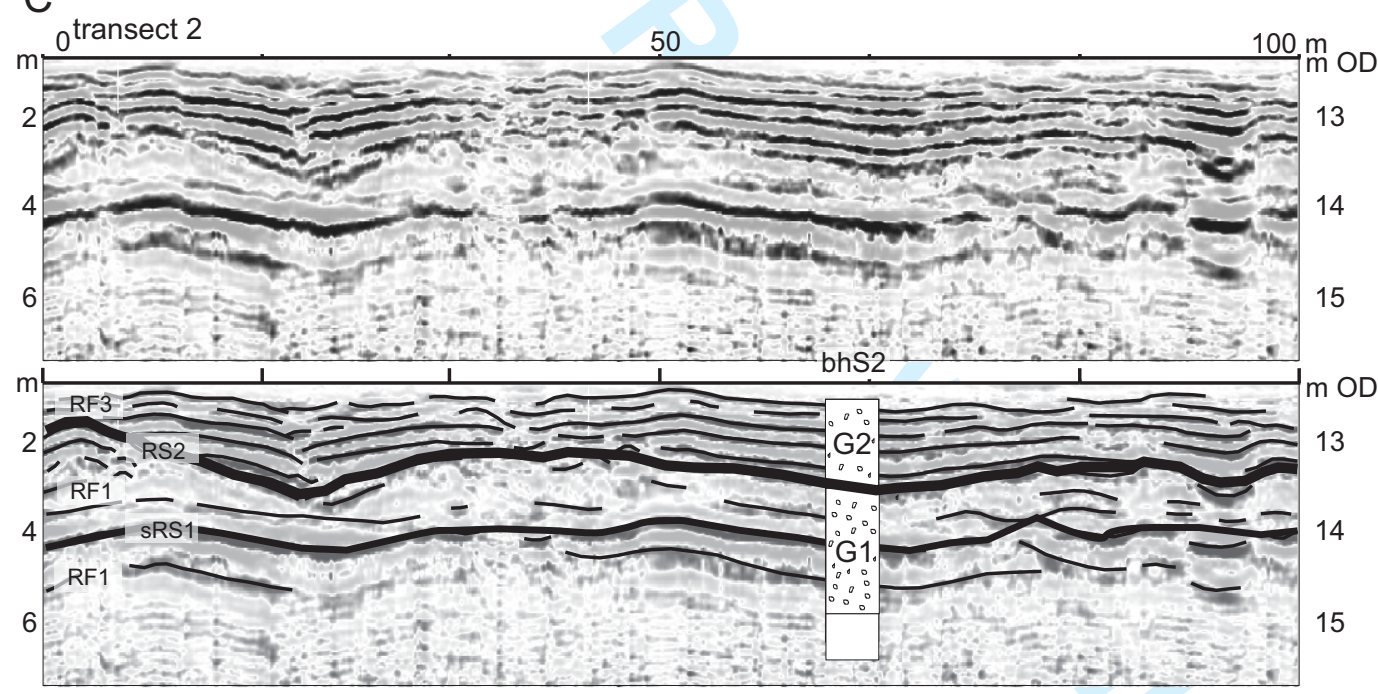

Major boudaries (RS)
between radar facies (RF)

Secondary boudaries (sRS) Radar reflections 

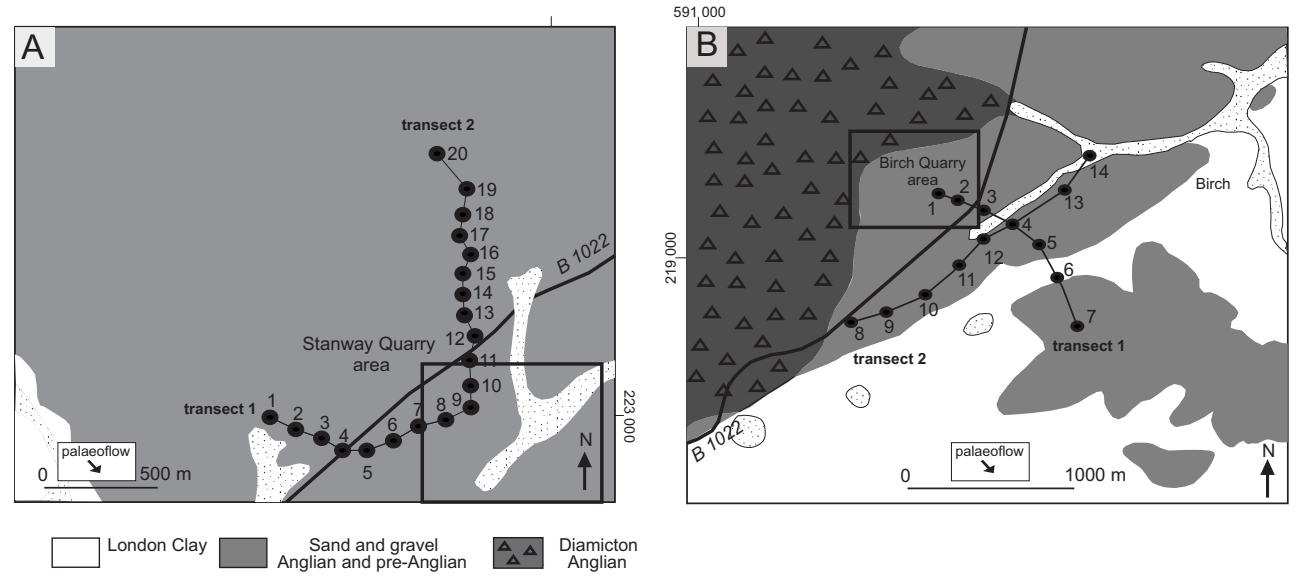

C
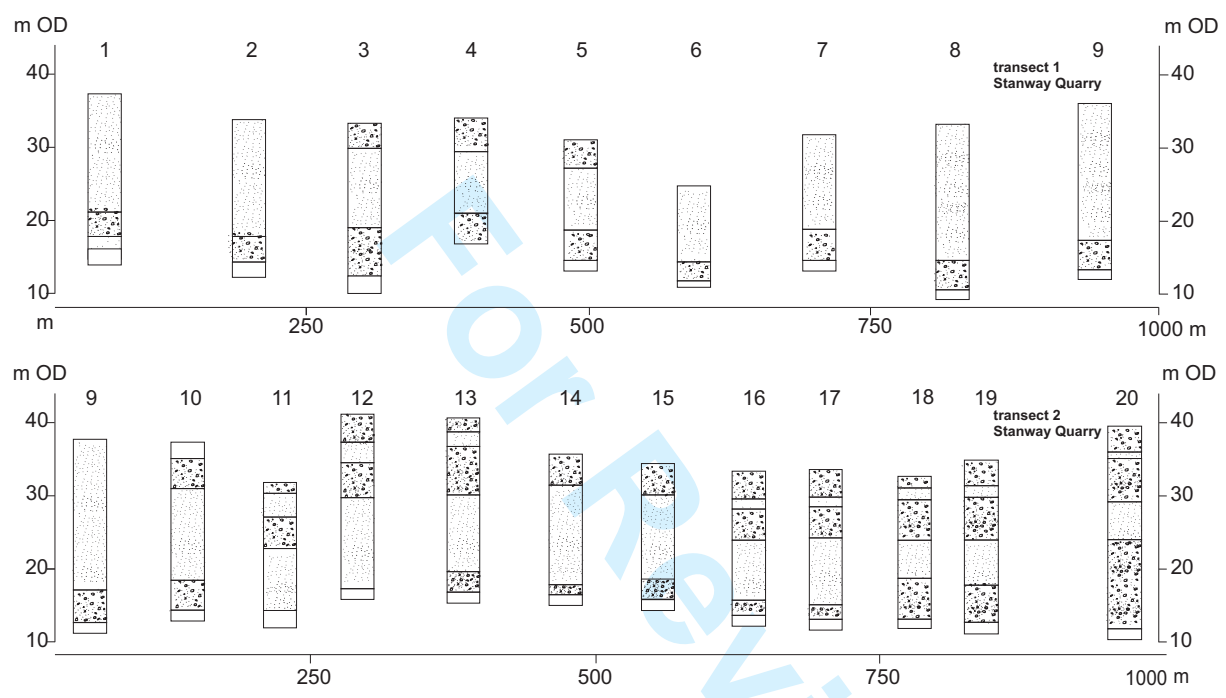

D

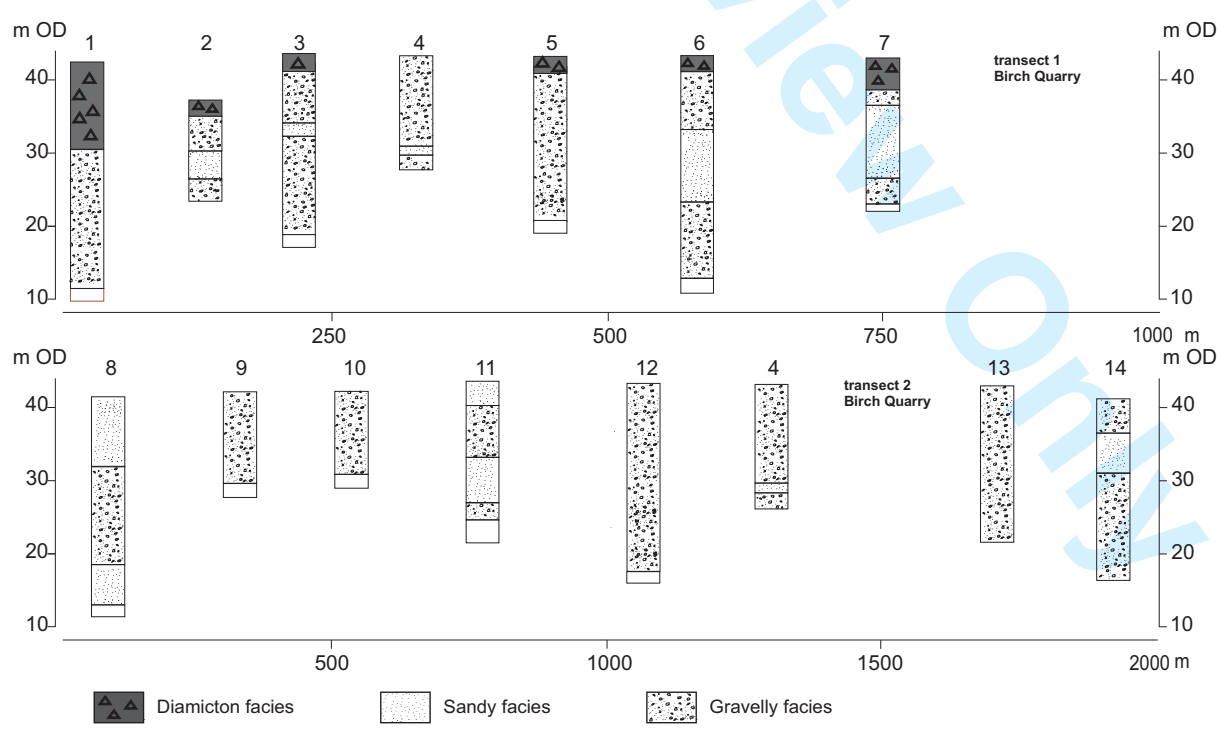




\section{Page 63 of 73}

\section{Boreas}
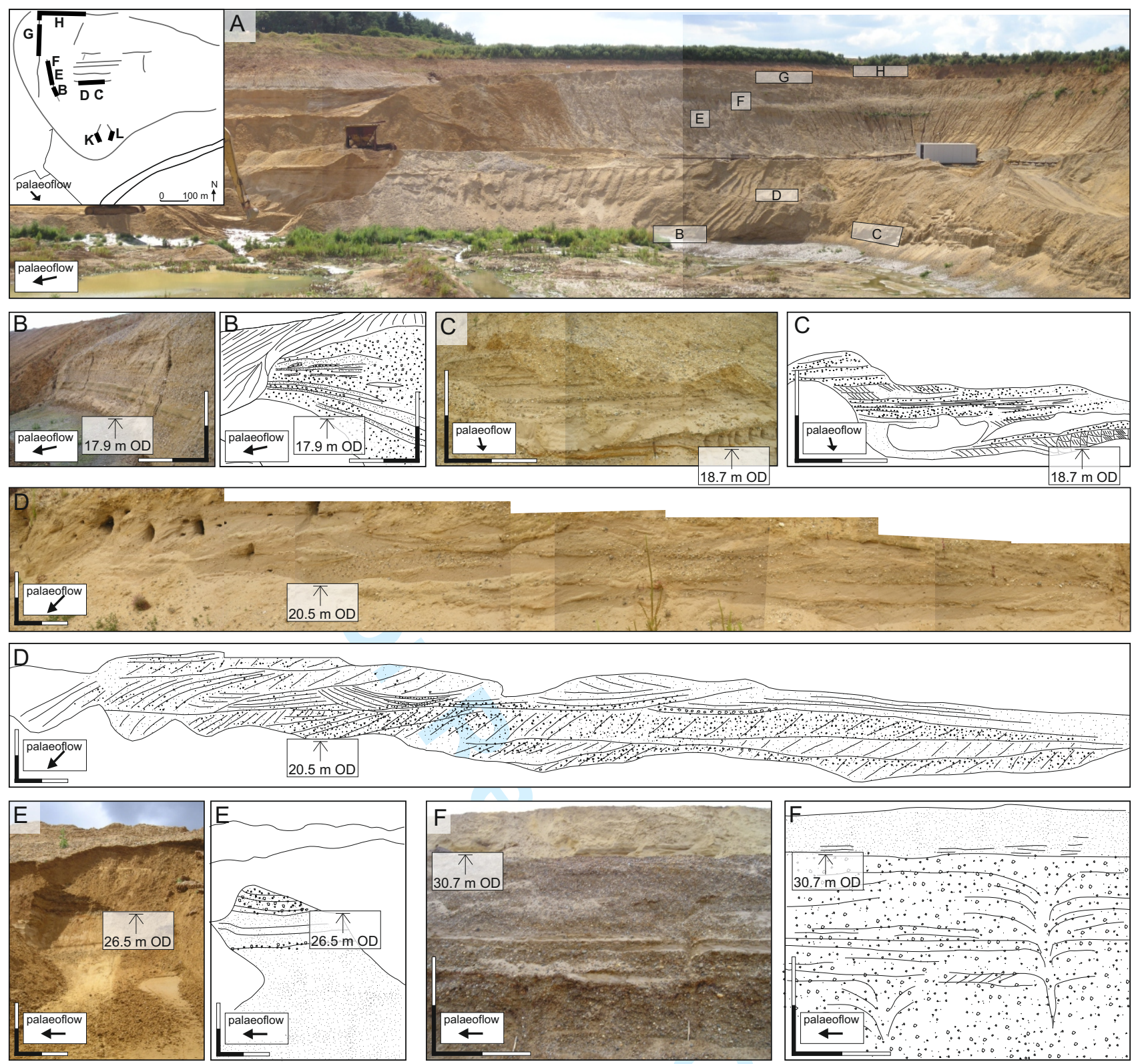

40

41

43 

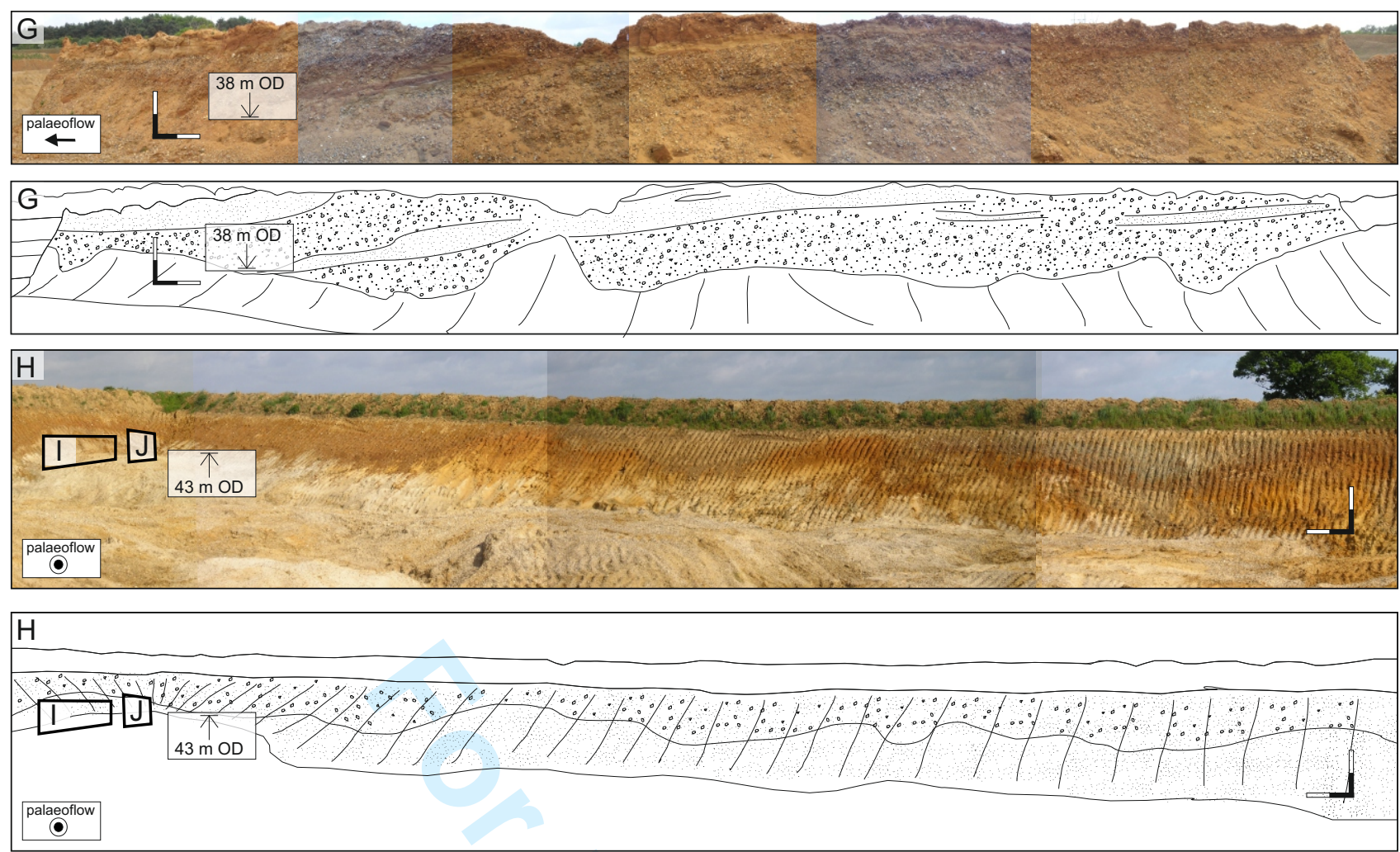
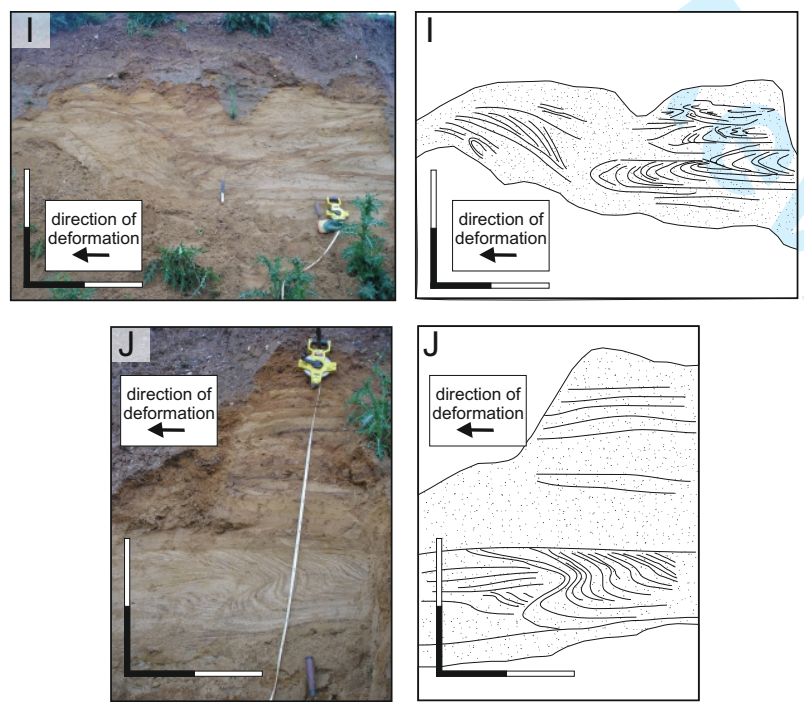
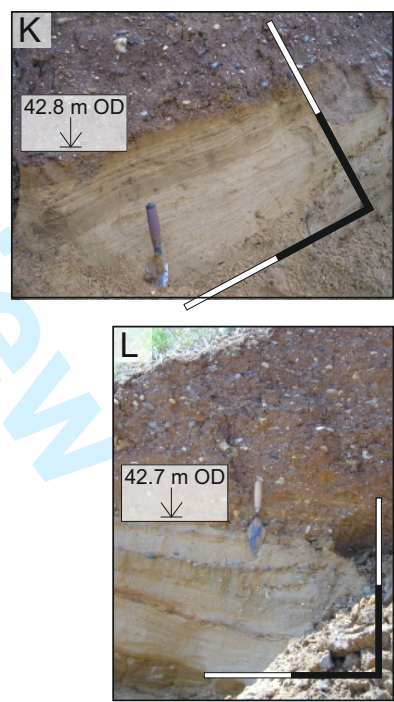
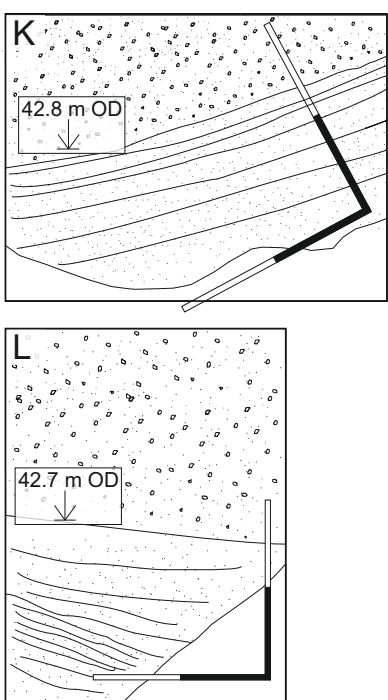


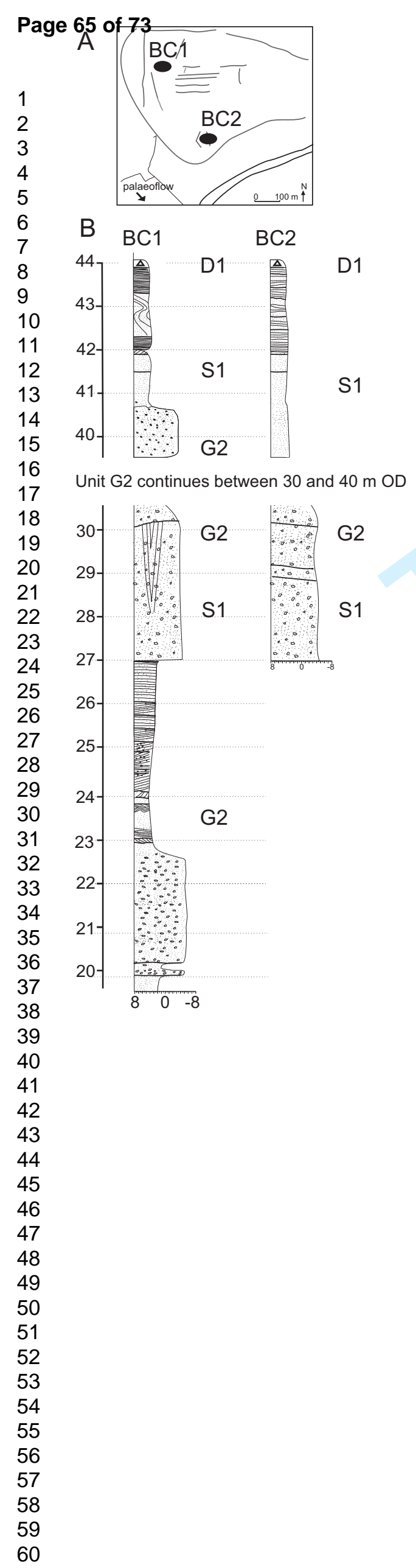

Unit $\mathrm{G} 2$ continues between 30 and $40 \mathrm{~m}$ OD 
A

m OD S proximal environment

$40-$

ice

$30-$

(1)

20

ice

$$
0
$$

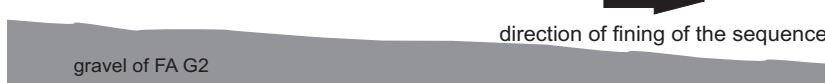

Stanway

distal environment $\quad \mathrm{T}$

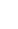




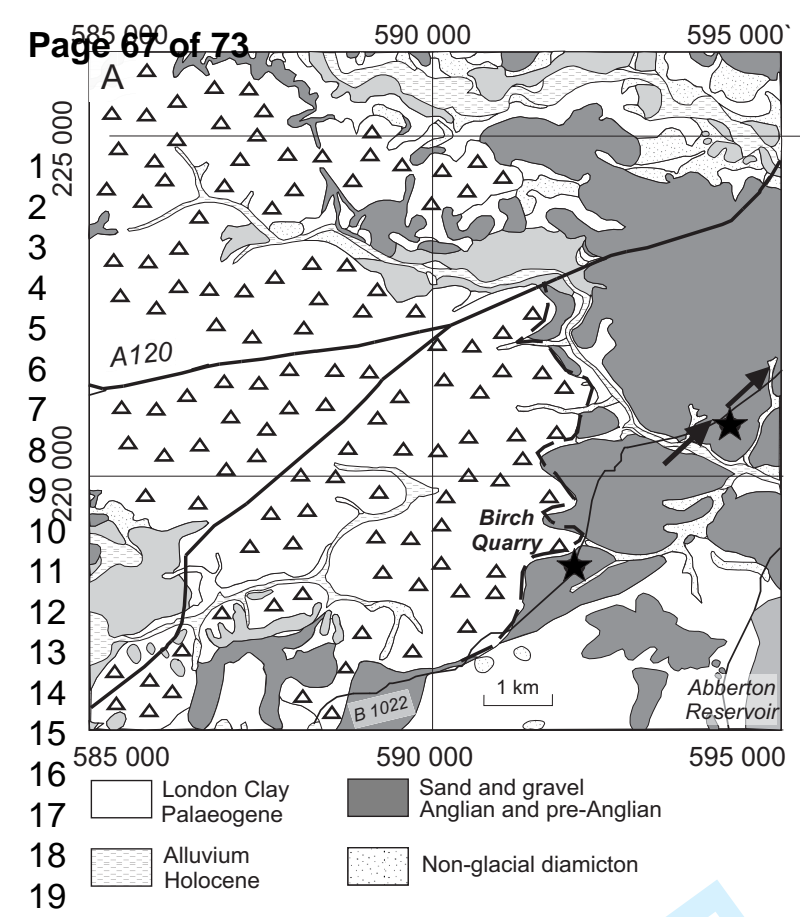

585000 Boreas $\quad 590000$

$595000^{\circ}$

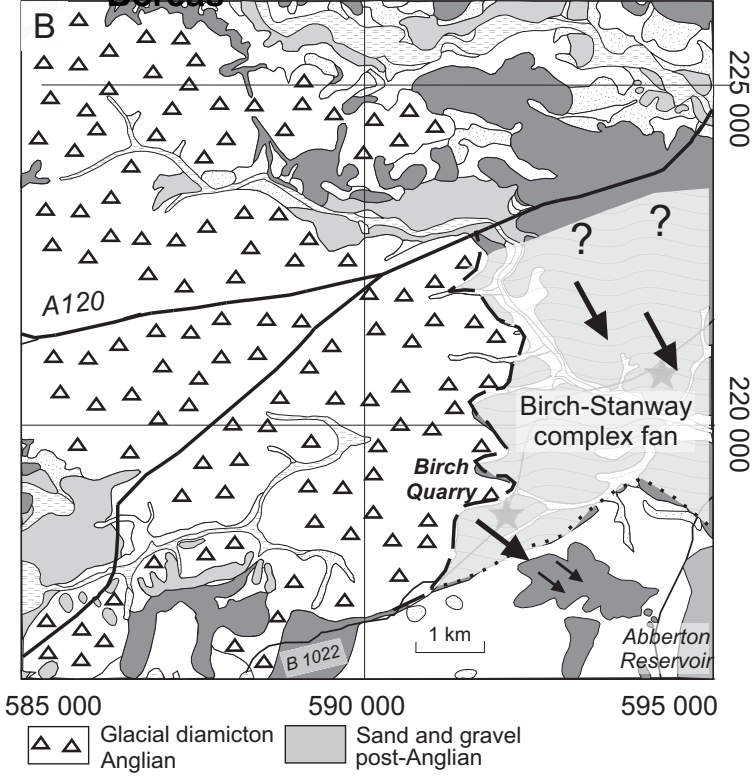

20

21

22

23

24

25

26

27

28

29

30

31

32

33

34

35

36

37

38

39

40

41

42

43

44

45

46

47

48

49

50

51

52

53

54

55

56

57

58

59 
Boreas

Page 68 of 73
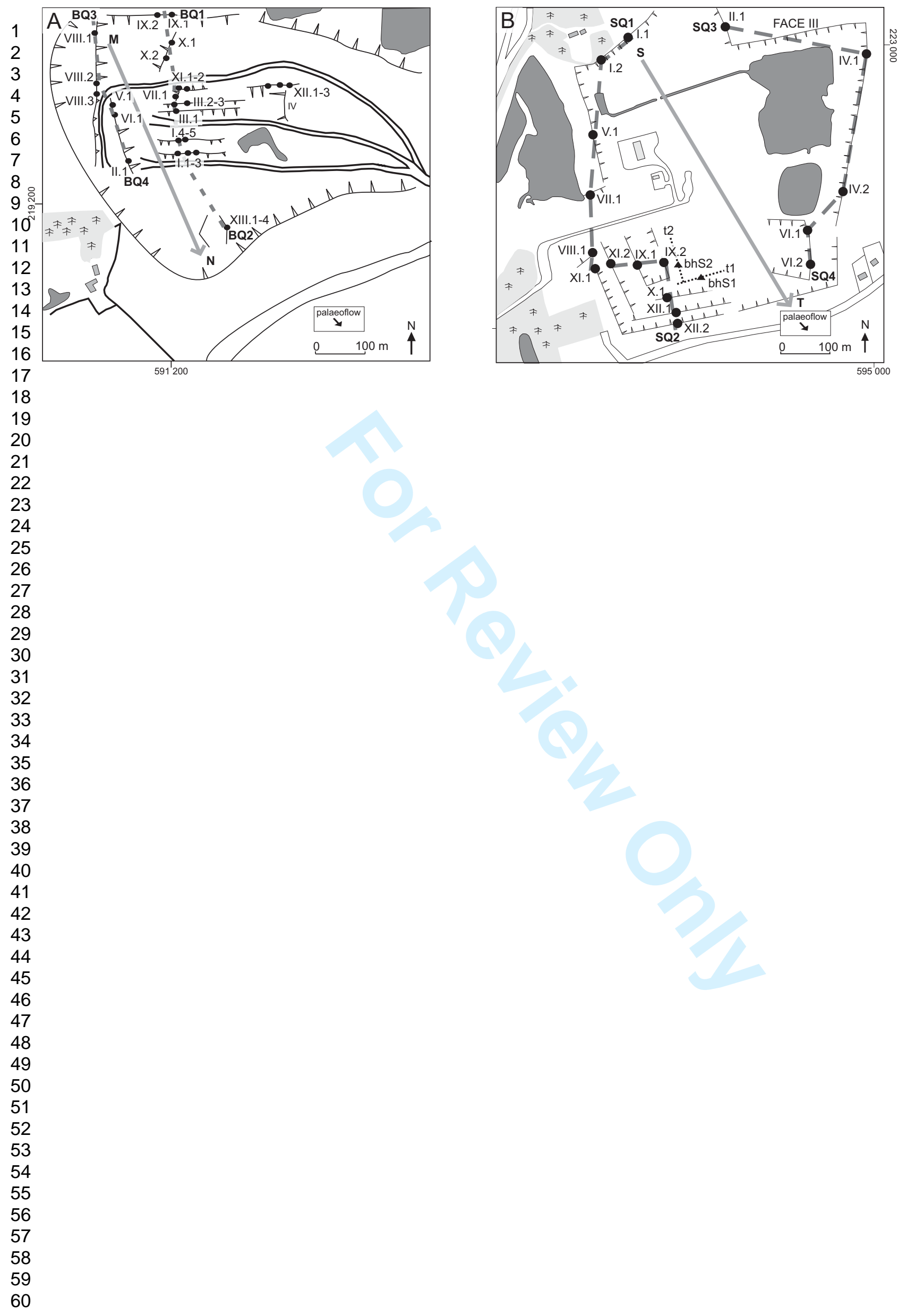


\section{Page 69 of 73}

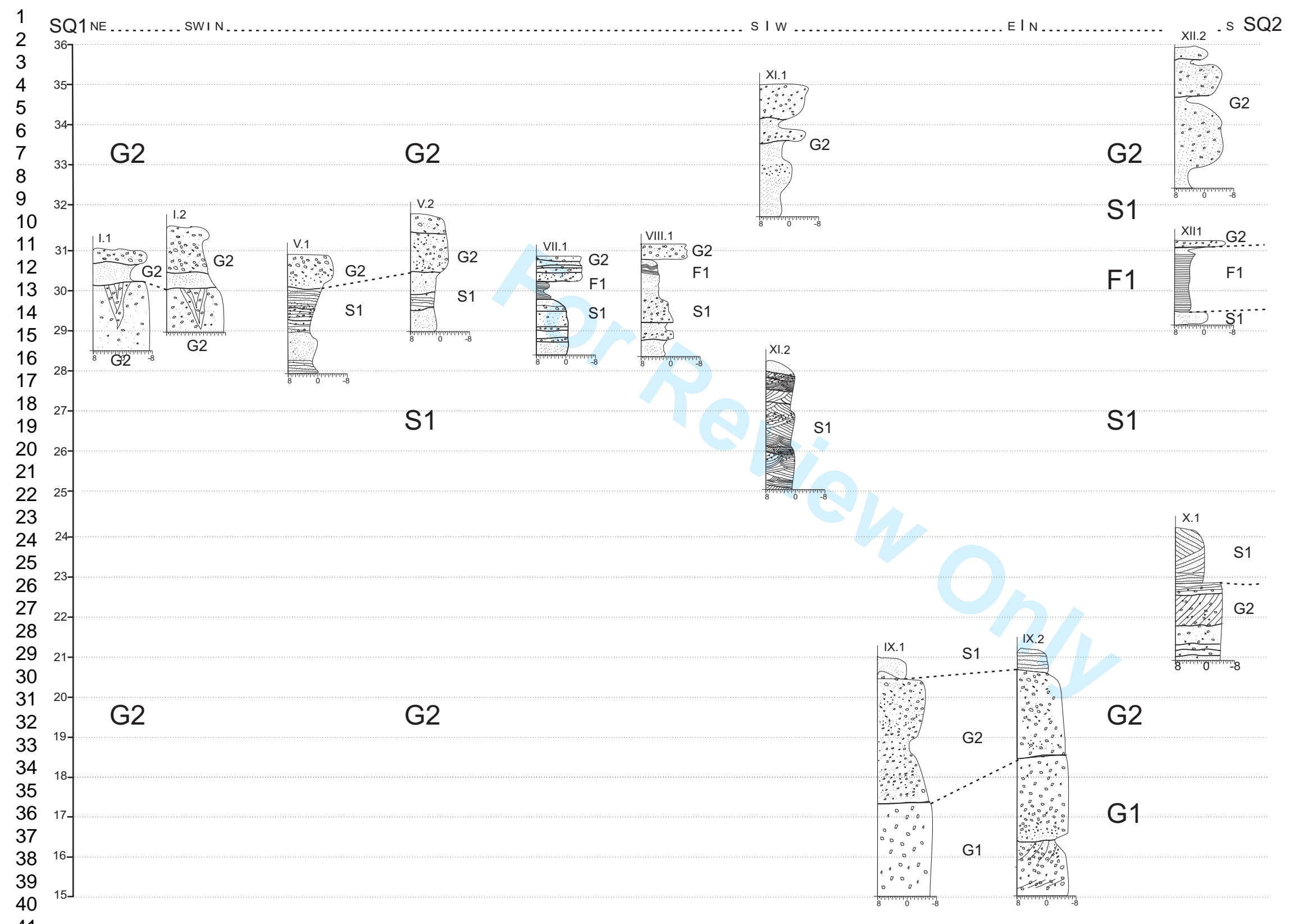


SQ3 NWW .

SEE I NNE s SQ4

1
2
3
4
5
6
7
8
9

10

11

12

13

14

15

16

17

18

19

20

21

22

23

24

25

26

27

28

29

30

31

32

33

34

35

36

37

38

39

40

41

42

43

44

45

46

47

48

49

50

51

52

53

54

55

56

57

58

59

60 


\section{Page 71 of 73

Boreas

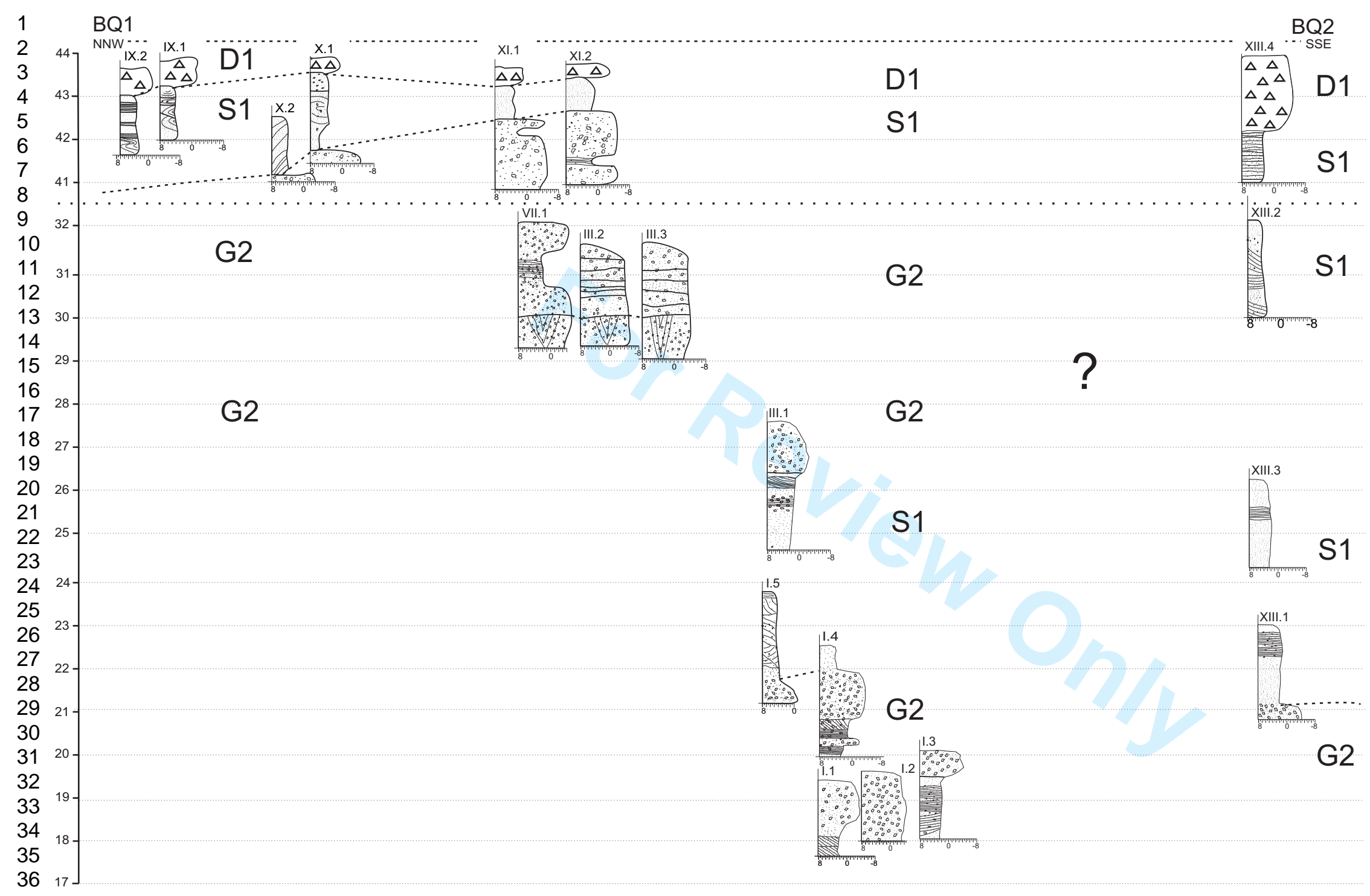




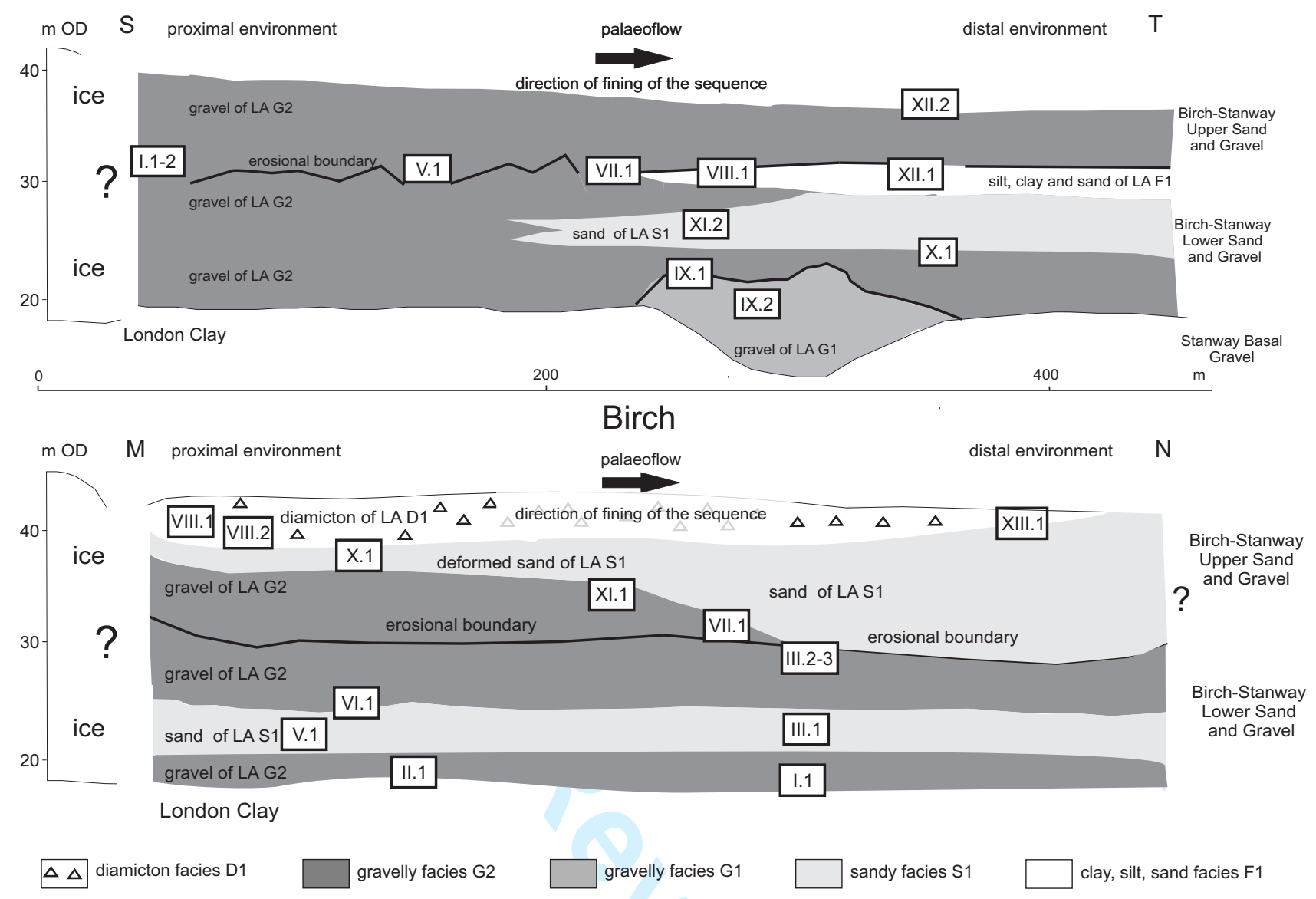

\section{Stanway}

